NBER WORKING PAPER SERIES

\title{
LATIN AMERICA'S INTRAREGIONAL TRADE: \\ EVOLUTION AND FUTURE PROSPECTS
}

\author{
Sebastian Edwards
}

Migue1 Savastano

Working Paper No. 2738

\author{
NATIONAL BUREAU OF ECONOMIC RESEARCH \\ 1050 Massachusetts Avenue \\ Cambridge, MA 02138 \\ October 1988
}

This paper was written for presentation at the Conference on "Economic Aspects of Regional Trading Arrangements, " Lehigh University May 25-27, 1988. Edwards gratefully acknowledges financial support from UCLA's Academic Senate and from the National Science Foundation. Edwards is a Professor of Economics at the University of California, Los Angeles and a Research Associate of the National Bureau of Economic Research. Savastano is a doctoral candidate at the University of California, Los Angeles. This research is part of the NBER's research program in International studies. Any opinions expressed are those of the authors not those of the National Bureau of Economic Research. 
NBER Working Paper \#2738

October 1988

\section{LATIN AMERICA'S INTRAREGIONAL TRADE:}

EVOLUTION AND FUTLRE PROSPECTS

\section{ABSTRACT}

This paper analyzes in detail the evolution of Latin America's international trade patterns, focusing on intraregional trade and on the formal attempts made to create free trade zones or custom unions. In particular, we assess the role of intraregional trade in the structural adjustment required by the Latin American debt crisis. The data analyzed show that the success of the commercial integration process has been quite limited. They also show that there has been no significant change in the OECD countries' share in Latin American imports or in the volume of intraregional trade flows since the early 1970s. Furthermore, the nature of the adjustment to the debt crisis of the 1980 s indicate that Latin American markets possess a rather limited capacity to absorb a substantial increase in regional exports in the current context. Thus, we conclude that the success of the required expansion in Latin American exports will depend more on the region's ability to design innovative mechanisms to penetrate the markets of industrialized countries than on the deepening of any regional trade integration process.

Sebastian Edwards Department of Economics UCLA

$405 \mathrm{Hilgard}$ Avenue

Los Angeles, CA 90024

\author{
Miguel Savastano \\ Department of Economics \\ UCIA \\ $405 \mathrm{Hilgard}$ Avenue \\ Los Angeles, CA 90024
}




\section{Introduction}

The attempts to integrate Latin American trade date back, at least, to the days of the independence wars. Simon Bolivar dreamed of a Spanish America integrated politically and economically. Although no serious efforts have been made to politically unify the region, throughout the years many attempts have been made at generating some sort of integrated economic zone within which free trade would prevail. Historically most of those attempts have been less than successful. Recently, however, some experts have argued that renewed efforts towards regional trade integration should be undertaken as a way to face the debt crisis.

There is little doubt that a permanent solution to Latin America's current crisis, and the resumption of sustained growth, will require a major effort to increase exports and to enhance the role of the external sector. It is especially important, then, to determine where those exports will go and who will Latin America import from in the future. In particular, it is important to evaluate what contribution could an expansion of intraregional trade make to this process.

The purpose of this paper is to analyze the evolution of Latin America's international trade patterns, focusing on intraregional trade and on the formal attempts made to create free trade zones or custom unions. The analysis also deals with the role of the Latin America's main trade partner -- the United States -- and discusses the role of Japan and the Asian NICs in the future evolution of Latin America's trade flows. The paper also discusses the possible future evolution of regional trade.

The paper is organized as follows: Section II provides a general account of the evolution of Latin America's commercial policies. The section is divided into two parts. The first provides a broad view of the 
evolution of protectionism in the region; the second part is a more detailed analysis of the region's attempts to formally integrate its international trade. Here the objectives and institutional characteristics of the most important multilateral trade agreements are reviewed and their achievements are evaluated. Section III deals with the recent evolution of Latin America's directions of trade; the origin of aggregate imports and the destination of aggregate exports are analyzed. Section IV provides a significantly more detailed and disaggregated analysis of the region's composition of trade with special emphasis on intraregional trade. Unfortunately, due to the lack of current data this analysis only covers until 1984. The information available, however, is detailed enough as to provide a broad picture of the recent trends. In Section $V$ we discuss the issue of protectionism - - both in the rest of the world as well as in the region .. and the future evolution of Latin America's trade. Section VI deals with the possible role of enhanced intraregional trade in the solution of the debt crisis. Finally Section VII contains the concluding remarks.

\section{The Evolution of Latin America's Commercial Policy}

\section{1 General Trends}

Until the 1930s the external sector in the great majority of the Latin American countries was highly opened; exchange controls were almost nonexistent, import tariffs were very low, and the "rules of the game" were strictly followed. All of this ended with the great depression; at that time an epoch of import substitution and protectionism began. 1

During the 1950s and 1960s, under the intellectual leadership of the United Nations Economic Commission for Latin America (ECLA/CEPAL), ${ }^{2}$ and its charismatic Secretary General Raul Prebisch, most of the Latin American 
countries embarked on ambitious industrialization programs based on import substitution. This strategy was based on the premise that high import tariffs and other impediments to international trade would provide temporary protection to the domestic manufacturing sector. According to this approach after some time the domestic firms would have "learned", and protection would not be necessary any more (Prebisch 1984). Things, however, did not work out as predicted by the theory, and protection became a permanent feature. As a result, in most of the Latin American countries the industrial sector developed under the barriers of protection; this industrial sector was largely inefficient and used highly capital intensive techniques (Krueger 1980, 1983).

During the 1950 s and first half of the 1960 s it became apparent that the import substitution strategy was losing dynamism. Although the easier and more obvious imports had already been substituted, these countries remained highly "dependent" on imported intermediate inputs and capital goods. At the same time the highly overvalued domestic currencies conspired against the development of a dynamic export sector, with the consequent scarcity of foreign exchange. ${ }^{3}$

During the late 1960 s a mild reaction against excessive protectionism started to take place in some countries. In Colombla, for example, there was an important move towards export promotion schemes (Diaz Alejandro 1976). A1so, and as is discussed in greater detail below, during this period some serious efforts were made to create comon markets comprising either all Latin American countries or subgroups of them. In that respect the creation of the Latin American Free Trade Association, the Andean Group and the Central American Common Market were particularly important. Although in some regards these integrationist schemes were successful, they 
did not turn around the region's economies, and in many cases the external sector . - and the excessive protectionism -. was still seen as the "weak link" by most analysts. ${ }^{4}$

During the second half of the 1970s a larger and larger number of countries began to recognize the benefits of export promotion, and some of them began to rationalize their external sector. This process was supplemented by significant debt inflows from the international banking system. This opening up process was particularly important in the countries of the Southern Cone (Edwards 1985, Calvo 1986). In August of 1982, immediately following Mexico's formal announcement that it was facing serious financial difficulties, the international financial comminity greatly reduced the amount of funds intermediated to the developing world. Even some countries, such as Colombia, which in no way faced payments problems, had serious macroeconomic disequilibria, or had accumulated debt at a very fast pace, were affected by this reduction in foreign lending. In fact, it is fair to say that the availability of foreign funds was reduced in a brutal way. For the developing world as a whole, external financing was reduced by almost 40 percent between 1981 and 1983. Moreover, the major debtors were forced to fully close a current account deficit that in 1982 exceeded $\$ 50$ billion in less than 3 years. By 1985 the aggregate current account had reached virtual equilibrium ( $\$-0.1$ billion). In order to achieve this significant adjustment these countries had to engineer a major turnaround in their trade balance, which went from an aggregate deficit of almost $\$ 7$ billion in 1981 to a surplus of more than $\$ 40$ billion in 1984 .

During the initial stages of the adjustment process, most Latin American nations resorted to an extraordinary increase in protectionism as the most rapid and effective (although not efficient) way of reducing 
imports. In some countries the extent of trade restrictions has recently been somewhat relaxed, while other have announced some easing up in the near future. In Chile, for example, tariffs were reduced to a 20 uniform level. Mexico has taken some steps towards reducing the coverage of licenses, while in Bolivia as part of the stabilization program aimed at stopping hyperinflation, quotas have been abolished and tariffs reduced. In many countries trade liberalization packages are being discussed as a part of conditionality agreements with the multilateral institutions. All in all, however, in mid-1988 the level of trade restrictions remain very high in most of the region.

\section{II.2 Latin America's Historical Attempts at Regional Trade Integration}

The first modern attempts at commercial integration date back to the late 1950s and early 1960s. The rationale for these attempts, however, cannot be found on the traditional (static) trade-creation effects predicted by the customs unions theory. ${ }^{5}$ Instead, commercial integration in Latin America was perceived and advocated as the only alternative to overcome the problems related to the inadequate scale of domestic markets. Also, it was thought that regional integration would help overcome the existing difficulties of substituting the importation of the full range of intermediate and capital goods

In effect, it was basically as an attempt to extend the import substitution strategy -- and as a response to the urgings of ECLA -- that six South American countries and Mexico established the Latin American Free Trade Area (LAFTA/ALALC) and four Central American nations created the Central American Common Market (CACM) in 1960. These attempts at commercial integration were followed by the creation of two other subregional common markets - the Caribbean Free Trade Association (CÁRIFTA) in 1965 and the 
Andean Group (AG) in 1969 .. and ended up with the replacement of LAFTA by the Latin American Integration Association (LAIA/ALADI) in 1980.

In general, the differences among these institutions are not restricted to the number and relative homogeneity of their members, but also lie on their attempted goals and on the mechanisms designed to achieve them, as well as on their accomplishments. As a way to provide a basic framework for the understanding of the current state and future prospects of this process, this section provides a brief review of the most salient features of the different attempts at commercial Integration in Latin America in the last three decades.

\section{II.2.1. The Latin American Free Trade Area}

The Treaty of Montevideo, signed in 1960 and put into effect on June 1 , 1961, created the Latin American Free Trade Area (LAFTA/ALALC) comprised of Argentina, Brazil, Chile, Mexico, Paraguay, Peru and Uruguay (the two remaining South American countries, Bolivia and Venezuela, joined the association only in 1966 and 1967, respectively). The main objective of LAFTA was the gradual elimination of trade barriers and the progressive reduction of tariffs affecting intraregional trade flows. The goal of an almost completely liberalized regional market was scheduled to be accomplished after a 12-year transition period of continuous multilateral negotiations. The countries agreed on following a product-by-product negotiation strategy regulated by GATT-type principles of most favored nation and reciprocity. The latter was designed to provide more favorable treatment to the least developed countries of the region (Bolivia and Ecuador).

In order to achieve its goal of a gradual liberalization of intraregional trade flows LAFTA established three mechanisms: the "national lists", the "common lists" and the agreements for industrial 
complementation. The items included in the "national lists" were those for which each country agreed to reduce nominal tariffs by at least $8 z$ per year. The negotiations concerning the products each country was to include in these lists were scheduled to be conducted annually. The "common lists", on the other hand, included those products in which all countries agreed to have fully liberalized - - i.e., zero tariffs and no quantitative restrictions - - intraregional trade by the end of the transition period. The Treaty established that negotiations regarding this list should be carried out every 3 years and that the members should progressively increase the number of items included on it, in order to fulfill the objective of having 758 of the intraregional trade subject to this treatment by 1972 . Finally, the agreements for industrial complementation were supposed to constitute the mechanisms for coordinating at a regional level the industrial policies in those sectors in which the volume of intraregional trade was too low or nonexistent.

This attempt at commercial integration, however, faced serious obstacles almost since its inception. Pressures for the extension of the original 12-year transition perlod began to build up just after the first round of negotiations. After successive postponements and amendments of the liberalization schedule, this was finally extended until 1980. On the other hand, despite an auspicious start, the number of items added each year to the "national list" of the member countries experienced a rapid and abrupt reduction. As can be seen in Table 1 , the total number of tariff concessions granted by LAFTA members on their "national lists" more than doubled between 1962 and 1968, but almost stagnated from then on. By 1968 the countries had already granted 93 of the total concessions they had given by the end of the IAFTA agreement in $19800^{6}$ 
The other two mechanisms designed by LAFTA performed even worse. Only one "common 1ist" was negotiated and approved in 1964, but it never became effective, while the agreements for industrial complementation covered very few sectors, most of which were dominated by multinational corporations located in the three larger countries (Argentina, Brazil and Mexico).

The relative failure of the negotiation mechanisms was also reflected in the sluggish evolution of the volume of intraregional trade. Table 1 shows that the percentage of LAFTA's exports directed to the regional market only increased from 7.68 to 11.48 between 1962-64 and 1971-72. After a decrease in the period $1973-74$ caused by the oil crisis, this ratio remained quite stable at a level lower than 148 until the dissolution of LAFTA in 1980.

A key factor to understand the very limited success of LAFTA in promoting a vigorous increase in the level of intraregional trade can be found in the type of products for which tariff concessions were granted. Most of the items included in the "national lists" of the member countries were either primary products (on which trade within the region had been traditionally based) or commodities that had never been produced in the region. In this sense, the slow acceleration in the volume of intraregional exports seems to have been just a consequence of making the whole scheme dependent on the intensification of the traditional patterns of trade within the region.

Among the different explanations that the literature on the subject has provided for this modest overall result of the LAFTA experience we have: 7 (1) the absence of a mechanism that would have prevented an uneven distribution of the costs and benefits of the integration process among the heterogeneous members of LAFTA; (2) the favorable effect generated by the abundance of capital inflows in the early 1970s on LAFTA countries' foreign 
exchange constraints; (3) the nonexistence of provisions for the coordination of macroeconomic policies within the members; (4) the costly bargaining process implicit in a product-by-product negotiation technique; and (5) the inherent conflict that exists between a domestic import substitution strategy and a commercial integration scheme. Even though there is no doubt that factors (1) through (4) played a role in the disappointing outcome of the LAFTA attempt, it can also be said that all of them were, in one way or another, a consequence of the conflict between the goals of import substitution and those of a genuine integration process.

In effect, the underlying rationale of all these explanations seems to be the existence of a basic misperception of the significant costs involved in the attempt to extend the import substitution strategy to a regional level. The fact that potential regional imports of manufacturing products were even more competitive with domestic production than the permitted imports from third sources made the highly protected import competing sector of each country to strongly oppose the scheduled liberalization. The large efficiency differentials among the industrial sectors of LAFTA members only exacerbated this problem. This also explains why the integration process experienced a halt in the late 1960s, precisely when its further progress required granting tariff concessions on the highly protected durable and nondurable consumer goods sector.

The reaction of LAFTA members to this paralysis of the integration process varied widely; it went from the early creation of the Andean Group by a subgroup of nations in 1969 , to the final replacement of LAFTA by the more modest, in terms of goals, Latin American Integration Association (LAIA/ALADI) in 1980. By that time, however, the trade orientation strategy of most countries of the region had already experienced a drastic change. 


\section{II.2.2 Central American and Caribbean Experiences With Common Market Arrangements}

\section{1) The Central American Common Market}

The first movements towards commercial integration in Central America consisted of a series of bilateral trade agreements established among the five countries of the region in the 1950s. The integration process was accelerated at the end of that decade when, with the assistance of ECLA, some of these countries attempted to extend their import substitution strategy by implementing a regional industrialization scheme based on "integration-industries" previously allocated among the members. However, those countries with a more advanced industrial sector (Guatemala and El Salvador) demonstrated their strong opposition to this approach by signing, together with Honduras, a free trade agreement ("Treaty of Economic Association") in February of 1960 . This agreement was ratified by Nicaragua in December of the same year with the signature of the "General Treaty of Economic Integration", which created the Central American Common Market (CACM/MCCA). ${ }^{8}$ The terms of the treaty implied the immediate adoption of free intraregional trade in most manufacturing commodities and the establishment of a five-year schedule for the elimination of tariffs on the remaining items (mainly agricultural products) as well as for the harmonization of a common external tariff structure. The treaty also considered the creation of a regional payments regime administered by a Central American Clearing House, which was established in July 1961.

There was remarkable progress during the first years of the treaty. By 1966 more than 948 of the items of the CACM tariff classification (NAUCA) were subject to free trade within the region and to a common external tar. iff. As a consequence, intraregional trade experienced a spectacular 
growth; Table 2 shows how the proportion of CACM's exports traded in the regional market increased from 7.88 to 24.28 between 1961 and 1968 . However, this transition towards a fully liberalized regional trade was marked by the continuous complaints of the poorer members of the agreement (Honduras and Nicaragua) regarding the asymetry in the distribution of the benefits of the common market. This discontent, reflected in these countries' balance of payments deficits and coupled with adverse external terms of trade in the late 1960s, led to the imposition of a 30 "temporary" surcharge on the common external tariff in $1967,,^{9}$ and prompted Nicaragua to implement discriminatory measures against the other CACM members in 1968. A related event was the July 1969 "Soccer War" between Honduras and E1 Salvador that resulted in the withdrawal of Honduras from the CACM in December of 1970 .

In spite of the disruptive effects of these circumstances, particularly of Honduras' withdrawal, an 1mproving external environment allowed the remaining four countries to continue with the intraregional free trade agreement during the 1970s. Moreover, the continuous attempts of Honduras to re-enter the common market had the effect of not altering drastically the pattern of trade within the region. In fact, Table 2 shows that by 1974 intraregional exports accounted for more than 25 of total exports of the region. The evolution of this ratio not only contrasts with the poor performance of LAFTA in the same period, but is also higher than similar indicators for all the other commercial integration groupings among developing countries.

The most common explanation given to the good performance of this integration attempt stresses the economic homogeneity of their members and the lack of political strength of their domestic import competing sectors. 
It is precisely because of these reasons that Cline (1983) sustains that the liberalization strategy followed by CACM cannot be generalized to broader commercial integration schemes in Latin America. Even if Cline's statement is correct, and despite the negative effects that the severe internal problems and the adverse external shocks surrounding the debt crisis have had on intraregional trade flows, the CACM stands out as the most successful of all the attempts at liberalizing intraregional trade that have been made in Latin America.

\section{ii) The Caribbean Experiences with Common Markets: CARIFTA and CARICOM}

The attempts at commercial integration among the very small and extremely open Caribbean economies date back to the mid-1960s. In 1965, articles of a Caribbean Free Trade Association (CARIFTA) were subscribed by Antigua, Barbados and Guyana. This agreement was ratified three years later (in May 1968), by eight other Caribbean countries (Jamaica, Trinidad and Tobago, Grenada, Dominica, St. Lucia, St. Vincent, Montserrat and St. KittsNevis-Anguilla); the remaining Caribbean nation, Belize, only joined the association in $1971 .^{10}$

The CARIFTA agreement immediately freed most of the trade among member countries from import and export duties and from nontariff barriers. A five year schedule for the elimination of intraregional tariffs was designed for the few import-substituting products exempted from the regulation. However, the agreement did not consider any measure related to the imposition of a common external tariff. Intraregional trade increased significantly after the establishment of CARIFTA; between 1967 and 1973 the share of intraregional trade rose from approximately 7.8 percent to 11 percent.

The gains from this integration process, however, were strongly biased in favor of the more developed countries of the agreement which accounted 
for more than 90 percent of intraregional trade. Given this asymmetry in the distribution of benefits, the less developed countries of CARIFTA exerted pressure for a broadening of the scope of integration. In particular, these countries were concerned with the establishment of mechanisms that could imply a more favorable treatment for them within the agreement. As a result of this situation the Caribbean Community (CARICOM) was established in August of 1973. Its objectives went further than commercial integration, since they also involved the harmonization of monetary and fiscal policies and the creation of planning agencies for agricultural and industrial development. Also, a common external tariff for imports from nonmember countries was established. Despite the almost immediate adoption of the common external tariff, the adverse external terms of trade caused by the oil shock prompted protectionist responses - - in the form of restrictive import licensing - from Guyana and Jamaica. This action not only affected negatively the level of intraregional trade -. which share in total trade dropped to $8 \%$ in 1975 and $7 \%$ in 1976 -. but also provoked antagonism and retaliatory responses from the other members of CARICOM. ${ }^{11}$ Although some conciliatory measures were subsequently attempted, the share of intraregional trade has remained in the neighborhood of 78 in the following years and the trade flows have still been heavily concentrated among the four more developed countries of the region. These facts seem to indicate that the wide differences in the economic size of the members, and the lack of diversification of their productive structures, constitute insurmountable obstacles for a successful commercial integration within this region.

\section{II.2.3 The Andean Group}

As pointed out in Section II.2.1, one of the consequences of the inoperacy of LAFTA was the formation of the Andean Group (AG) by five of its 
middle-size members. In 1969 Bolivia, Colombia, Chile, Ecuador and Peru signed the Cartagena Agreement with the explicit goal of avoiding the inconsistencies that determined the poor performance of LAFTA. ${ }^{12}$ These optimistic expectations were based on the relative economic homogeneity of the AG members and on the by-then widely accepted conception that a comprehensive industrial planning strategy was the prerequisite of a successful deepening of the integration process.

Within these expanded framework, the AG established as its objectives: (1) a progressive liberalization of intraregional trade; (2) the gradual achievement of a common external tariff; (3) the emphasis on regional investment programs designed to balance the costs and benefits of the integration process among the member countries, and (4) the establishment of a code for the common treatment of foreign direct investment. The specific mechanisms designed to achieve these objectives allowed for a special treatment of the less developed countries of the region .. Bolivia and Ecuador.

In this sense, with respect to the first two objectives, the AG countries agreed that Colombia, Chile, Peru and Venezuela should carry out an automatic yearly reduction of their average tariff level of the order of 78 of the infial tariff structure, in order to achieve a complete liberalization of their trade flows by $1980 .^{13}$ By that time the common external tariff of the region was supposed to be already in practice. In the cases of Bolivia and Ecuador, however, this liberalization was expected to start only in 1980, and to be completed by 1990. Although the automaticity of this liberalization schedule contrasts with the inefficient product-by-product strategy adopted by LAFTA, the AG scheme exempted several items from the proposed tariff reduction. It was argued that the allocation of industries in those sectors should be a result of the regional investment program. 
With respect to the last objective -. the establishment of common rules governing foreign investment - the AG contemplated two mechanisms that were supposed to alter significantly the industrial configuration of the region: the reallocation of some multisectoral industries that already existed among the member countries .- as a way to distribute more equally the potential benefits provided by the expanded market - - and the programing of new investments in eight "strategic" industrial sectors. ${ }^{14}$ Finally, the Andean countries agreed to maintain permanent negotiations on the issue of foreign direct investment until a code for its common treatment could be unanimously approved.

Although the results obtained by the Andean Group are better than those achieved by LAFTA, they are much less spectacular than what its members originally expected. The proportion of AG's exports traded in the regional market increased from a low value of 1.7 percent in 1970 to 4.5 percent in 1979, and since then has remained stable in the neighborhood of 4 percent. The main factors determining this meager achievement seem to have been the excessive number of exemptions granted on the tariff liberalization schedule, the serious difficulties faced by the members in the design of the common external tariff and the inconsistency between the regional industrial planning strategy and the particular trade regime prevailing on each of the member countries.

The importance of the generalized granting of exemptions is reflected by the fact that, as of 1980 , more than 25 percent of the items included in the NABANDINA tariff nomenclature had not been subject to the tariff liberalization process. On the other hand, the differences in the level and dispersion of the protective structure of the AG members generated divergent positions regarding the appropriate timing, and the optimal level of the 
common external tariff. The problem was exacerbated by the overvaluation of most of the members' real exchange rates and the existence of different exchange rate practices within the region that made it more difficult to measure the effective rate of protection recelved by any activity in some particular country. ${ }^{15}$ overall, the fact that the members' positions in this particular respect seemed irreconcilable, and that the common external tariff was never accomplished, influenced negatively the commercial integration process within the Andean Group.

The failure of the regional industrial planning strategy also contributed to the slowdown of the integration process. As of 1985 only three of the eight investment programs in "strategic" sectors had been approved (on the petrochemical, metalmechanic and automobile sectors) and not a single regional reallocation of the previously established multisectoral industries had been carried out. This put in evidence, once again, the incompatibility of the national industrialization objectives with the attempts to extend the import substitution strategy to a regional level; it seems extremely difficult for domestic producers to internalize the potential benefits stemming from a regional liberalization, even if the latter is carried out properly.

Finally, the attempt to coordinate the region's position towards direct foreign investment ended up constituting another disruptive factor. The approval of the Andean Code for Foreign Investment -- better known as Decision 24 .. which severely limited the share of foreign capital in industries operating within the region, provoked the withdrawal of Chile from the Andean Group in 1976 and caused a slight decrease in the inflow of this type of private capital to the remaining members. 
As a whole, then, the mechanisms designed by the AG for deepening the integration process among its members (the industrial programming scheme and the common external tariff), have not been successful. However, there seems to exist a consensus in the sense that with a less interventionist approach and a more comprehensive liberalization, there are still significant gains to be obtained from a commercial integration arrangement within this region.

\section{II.2.4 The Latin American Integration Association}

The recognition of the benefits of export promotion policies and the adoption of a more outward oriented strategy by most Latin American countries in the late 1970 s, coupled with the poor performance of the comprehensive integration processes attempted until then, determined the replacement of LAFTA by the Latin American Integration Association (LAIA/ ALADI) in 1980. This new arrangement substituted the ambitious goal of establishing a free trade area within Latin America for the more pragmatic objective of facilitating the negotiation of bilateral commercial agreements that might be later generalized to other countries of the region.

In this sense, the basic mechanisms designed by LAIA are bilateral tariff negotiations - - that should allow for the possibility of being later on extended to other members - - and the granting of regional tariff preferences by each of the member countries. These tariff preferences, however, are not subject to any pre-determined schedule and do not intend to be a part of a common external tariff for the region.

The increased efficiency of the negotiation strategy adopted by LAIA, together with the realism of its objectives, reflect a clear change in the expected role of commercial integration arrangements in Latin America. From being conceived as the extension of domestic import substitution strategies to a regional level, they are now perceived as a component of an overall 
outward-oriented strategy that can contribute to enhance export growth for the region as a whole, without discriminating excessively against other trade partners.

\section{Latin America's Intemational Trade: Aggregate Trends}

In this section we analyze the evolution of Latin America's direction of foreign trade at an aggregate level. Table 3 contains data on the dollar value of imports and exports for fourteen Latin American countries for selected years between 1970 and 1985. This table shows that for most countries the (nomina1) dollar value of imports peaked between 1980 and 1982 , only to experience a dramatic fall in the years following the eruption of the debt crisis. As can be seen, in every single country the (nominal) dollar value of imports in 1985 was well below its 1980 level. For these 14 countries as a whole the (nominal) dollar value of imports was, in 1985, 36 percent below its 1980 value. Moreover, when expressed in real dollar terms, 1985 total imports are 45 percent below their 1980 value! ${ }^{16}$ of course, this mainly reflects the reduction in imports required by the adjustment programs implemented by these countries after the 1982 debt crisis that was discussed in Section II.1. The evolution of the value of exports in Table 3 also reflects the effects of the adjustment programs. In a number of these countries - Argentina, Brazil, Ecuador and Mexico -. the value of exports was in 1985 significantly above its 1980 value. This was achieved in spite of the fact that for most of the countries in the region the international prices of their exports declined quite substantially during the period (see Edwards 1988a).

Table 4 contains data on an indicator of these economies degree of openness: the ratio of total trade (imports plus exports) to GDP. Although 
the index differs from country-to-country, it is still possible to draw as a general pattern of behavior that there was a fairly significant increase in the degree of openness in the 1970s. This general move towards greater openness is revealed both when 1975 is compared with 1970 as when 1980 is compared with 1970. Generally speaking, the available evidence strongly indicates that the 1970 s was a decade where most of the nations of Latin America became more open to the rest of the world. In fact, Edwards (1988d) shows that this claim is supported by the evolution of the level of import tariffs and other impediments to trade during this period. Table 4 also shows that during the first half of the 1980 s the trend towards greater openness was drastically reversed, with the openness index exhibiting a sharp drop for most countries. This, of course, was partially the consequence of the debt crisis and of the significant cut in imports that the adjustment policies required. As can be seen in Table 4 , in the case of the total trade to GDP ratio, in 9 of the 14 countries there was a decline between 1980 and 1985.17

\section{1 The Origin of Aggregate Imports}

In this subsection we focus on the recent evolution of intraregional trade by analyzing the behavior of different countries shares of the value of Latin America's imports at an aggregate level. In order to have a general picture and a better understanding of the way in which regional trade has performed, we also look in some detail at the way other countries' shares of regional imports have evolved. In particular we inquire on how the share of the OECD -- which comprises the region's most important trade partners - has evolved through time.

Tables 5 contains data on the percentage distribution of the value of imports for 14 Latin American countries for 1977-86. These data give us 
information on what fraction of the U.S. dollar value of each of these countries' imports came from industrialized countries, what share corresponded to intraregional trade - imports from within Latin America and the Caribbean - and what proportion came from the rest of the world.

Several facts arise from this table. First, notice that the distribution of the origin of imports varies significantly across countries. While in some of them the industrialized countries' share in total imports is in the 70 to 80 percent range, in others it is approximately 50 to 60 percent, while still in others it is in the order of 30 percent (i.e., Uruguay). Another interesting fact, that due to the aggregation does not emerge from the table, is that for the great majority of the Latin American countries there have been no perceptible changes in the proportion of imports coming from the U.S. ${ }^{18}$ Third, in some of the large and medium size countries either in 1982 or 1983 there is a slight drop in the share of imports coming from the industrialized countries (Argentina, 1982; Brazil, 1982; Chile 1982 and 1983; Mexico, 1983). Finally, in 8 of these countries there was a slight increase in the industrialized countries market share in 1985 and 1986 (Argentina, Brazil, Mexico, Uruguay, Venezuela, Colombia, Costa Rica and Ecuador).

With respect to intraregional trade, it is interesting to note that in the years corresponding to the debt crisis, and until 1983 or 1984, in almost every country there was a significant increase in the share of imports coming from the region. The reason for this has mainly to do with the way in which the import compression that followed the crisis was distributed across countries. Most Latin American nations reduced imports from every source; however, during the initial years of the crisis the drop in total imports greatly exceeded the decline in imports from the region. This 
increase in the share of intraregional imports was reversed in most countries in the last few years. This reflects, to a large extent, the converse of the phenomenon of 1982-83. As these nations have been able to increase their total imports, these have mainly come from outside the region. Overall, Table 5 shows that the share of aggregate imports coming from the region stood in 1986 significantly above its level in the late 1970s in most of the middle-income and low-income Latin American countries. For the majority of upper-middle income countries of the region, however, the share of intraregional imports has remained rather stagnant, or has even decreased - as in Mexico -- in the last decade.

\section{2 The Destination of Aggregate Exports}

Table 6 contains data on the regional destination of aggregate exports for a group of 16 Latin American countries for 1970-83. Given that this table permits us to assess which markets sustained the aggregate expansion of exports from the region in the adjustment period, an additional refinement has been made by explicitly identifying the export shares of LAIA/ ALADI, the U.S. and Japan.

A number of interesting facts are revealed by this table. First, the last two years show a reversal of the declining trend that characterized the evolution of the share of exports going to the OECD. Furthermore, regional exports to the U.S. have increased substantially after the debt crisis. This fact seems to indicate that the U.S. market has absorbed most of the regional attempt to close its current account gap. Second, after reaching a peak in 1980, intraregional exports have experienced a significant decline. This implies that the regional market has not been able to couple with the region's efforts to increase its foreign exchange earnings. The latter becomes evident if we note that in 1983 and 1984 the proportion of intra- 
Latin American exports reached their lowest value since 1970. Finally, another important trend captured in Table 6 is the steady increase in Latin American exports going to the rest (i.e., non-Japan) of Asia. In general, then, the aggregate trends seem to indicate that the regional market possesses a rather limited absorption capacity for new Latin American exports, at least during periods in which the region as a whole is trying to solve acute external disequilibria.

\section{Latin American International Trade: Disaggregated Data}

In the preceding section we investigated the evolution of Latin America's aggregate imports and exports. In this section we ask what is behind these aggregate data. In particular we inquire on which specific products does Latin America import from whom and exports to whom. As in the previous section our main interest is with the evolution of intraregional trade.

The Economic Commission for Latin America (ECLA/CEPAL) constructs fairly detailed and very reliable data on the region's directions of trade. Unfortunately in their effort to clean up the new data obtained from UNCTAD, they take a long time checking and rechecking the figures. This means that any study that wants to rely on these quality data has to use time series that end some years back. This paper is no exception; the disaggregated data discussed here only cover the period up to 1984. At this point we can only rely on some preliminary indicators -- including some preliminary ECLA figures - to predict how these directions of trade have evolved in the last 3 years or so.

ECLA collects disaggregated data at the one digit SITC level; thus in the analysis that follows it will be possible to distinguish between the following goods' categories: 
- Category 0: Foodstuffs and Live Animals

- Category 1: Beverages and Tobacco

- Category 2: Raw Non-Food Materials, except Fuel

- Category 3: Fuel and related products

- Category 4: 0il, greases and waxes of vegetable and animal origins

- Category 5: Chemical products

- Category 6: Manufactured products

- Category 7: Machinery and transport equipment

- Category 8: Other manufactured goods

- Category 9: Other commodities.

IV.1 Composition and Origin of Latin American Imports: Disaggregated Trends

Table 7 shows the composition of imports in our 16 Latin American countries taken as a whole. It reveals that the bulk of the region's imports has always been concentrated on the manufacturing sector (categories 5, 6, 7 and 8), with capital goods (category 7) being the most important item. However, it also shows a clear decline in the import shares of categories 6 and 7 that has been explained by a substantial increase in the relative importance of fuel imports (category 3 ).

In order to isolate the effects of the oil shocks, which affected asymmetrically the countries of the region, Tables 8 and 9 provide disaggregated information on the distribution of different categories of non-fuel imports among the intraregional market, the U.S. and Japan for 12 uppermiddle-income and middle-income Latin American countries. The disaggregation used here distinguishes between primary and manufactured products, obtained in the following way: (i) Primary products: Categories $0,1,2$ and $4 \ldots$ as defined above, (ii) Manufactured products: Categories 5, 6, 7 and 8 . The tables also include information on the dollar value of 
imports of each category to get an idea of their relative magnitudes.

From these tables it is possible to detect some common patterns across countries. First, with the exception of Uruguay and Paraguay, the U.S. remains as the most important supplier of manufactured imports to the region. The range of the U.S. share of this type of imports in Latin America goes from a low 17 percent -- in the case of Paraguay -. to as high as 67 percent - - in the case of Mexico. A second interesting pattern is related to the increase in the share of intraregional imports. In most Latin American countries, Mexico being the major exception, this increase in the participation of imports from within the region has constituted the counterpart of the slight loss of competitiveness experienced by the U.S. and some other OECD countries in the last decade. As mentioned in the previous section, this phenomenon was particularly clear in the asymmetric compression of intraregional imports during the enormous adjustment provoked by the debt crisis. However, it is also clear form the table that, perhaps with the exception of Argentina, the absolute magnitude of the share of manufactured imports from within the region is relatively large only for the smaller countries of Latin America.

With respect to agricultural products, it is important to note the increase in the share of imports coming from the U.S. Except for the cases of Argentina, Chile, Uruguay and Paraguay, the U.S. has displaced other Latin American and Caribbean countries as the main provider of these type of goods. Moreover, by 1984 some of these countries imported almost half of their primary products from the U.S.

A further disaggregation of these trends is provided in Tables 10 and 11. They show how each of the two more important Latin American integration schemes (LAFTA - - which later on became LAIA - - and the CACM) distribute 
their imports of the different "categories" of goods among the different suppliers. Each cell in each of these tables indicate what proportion of that particular category of good is imported by that integration scheme from that specific supplier. Also, the last column of these tables reflect the distribution of total imports from the region among the different suppliers.

In this way, Table 10 shows that imports from the members of LAFTA-LAIA have been concentrated on categories 7 (machinery), 5 (chemicals), 3 (fuel), 2 (raw materials) and 0 (foodstuffs). With the exception of fuel, which is mainly imported from OPEC countries, the OECD countries have been, by large margin, the most important suppliers of these goods to the region. The table also reveals that the increase in the share of intraregional imports of manufactures (category 6) and chemicals (category 5) represent the major achievement of this integration scheme in the recent years. What is even more important is that this increase in intraregional imports coincided with the adoption of the more pragmatic approach of the LAIA agreement - - as opposed to that of LAFTA - - and, more recently, with the drastic adjustment prompted by the debt crisis. Finally, this table also shows that the shares of the other integration schemes (CACM and CARICOM) on the imports of LAIA members have been almost insignificant, although this fact may be explained by the enormous differences in the size of the countries involved in each group.

As shown by Table 1I, the distribution of imports by origin in the countries of the CACM is somewhat different from that of the LAIA members. Although the OECD countries also constitute the major providers of all types of goods, except fuel, to the CACM, the countries from within this region have consistently remained as the second most important suppliers of imports. The significant difference in the magnitudes of the share of 
intraregional imports of the CACM and LAIA arrangements is a reflection of the relative success of the integration process in Central America already discussed in subsection II.2.2. The substantial decline in the CACM share of intraregional imports in the recent years, on the other hand, has to be interpreted with caution since it can be just a consequence of the political turmoil that has characterized the region since the late 1970s.

\section{2 Structure and Destination of Latin American Exports: Disaggregated Trends}

Givèn the major role that a significant increase in Latin American exports will play in the achievement of a long lasting solution to the region's pressing economic problems, it is important to assess what and to whom will Latin America export in the following years. The analysis of the aggregate trends of regional exports made in subsection III. 2 have already shown that the intraregional market enbodied a somewhat limited capacity to absorb the substantial increase in exportable output from the region in the mid-1980s. The disaggregated data on the composition of regional exports presented in this subsection will permit us to identify the type of exports that determined this outcome.

The data in Table 12 describe the evolution of the composition of total and Non-Fuel exports of our sample of 16 Latin American countries. Several facts emerge from this table. First, the share of exports of foodstuffs and agricultural products (category 0 ) has declined steadily throughout the period. Second, exports of fuel have increased in importance both as a result of the increases in the price of oil and of the larger gas and oil production in the region. Third, manufactured exports corresponding to categories 5 (chemicals) and 7 (machinery) have experienced an important increase in recent years. This trend is more clearly captured in the second 
panel of the table that excludes fuel exports: whereas in 1970 categories 5 and 7 represented no more than 6 percent of non-fuel exports, in 1984 they accounted for 19.2 percent. Finally, these data also show that exports of manufactures (category 6) have mostly maintained their relative importance throughout the period, accounting for less than 20 percent of non-fuel exports.

In order to determine which trade partners have supported the export expansion of Latin American countries, Tables 13 to 15 provide disaggregated information on the destination of non-fuel exports for the Latin American nations grouped according to their per capita income. ${ }^{19}$ These tables show that those upper-middle income Latin American countries that achieved a substantial increase in manufactured exports in the last years (Argentina, Brazil, Mexico, Venezuela and even Chile), have experienced a decline in the proportion of their exports directed to the regional market. In most cases this lower share of intraregional exports has implied an increase in the share of exports to the U.S., confirming the aggregate trend captured by Table 6. The intraregional share of manufactured exports in all the other countries has not exhibited that much of a trend, having been this share particularly large for the Central American countries. With respect to primary exports, these tables reflect that the U.S. constitutes the most important market in the majority of cases. Although the U.S. share has declined in recent years, the share of intraregional exports of this type of products, which has rarely been larger than 20 percent, has not shown an increasing trend.

The more disaggregated data contained in Table 16 reveal even more clearly how the substantial increase in manufactured exports of the LAIA members has been mostly absorbed by OECD countries. Between 1980 and 1984 
the regional exports of this type of goods increased by 37 percent (U.S. $\$ 6.7$ billion), while the share of intraregional exports in all these categories declined drastically. Actually, the exports of these goods to the region only increased by 0.4 billion during that period.

On the other hand, the data in Table 17 shows that the large share of intraregional exports of manufactures in the $C A C M$ has not experienced a significant reduction in recent years. However, this group of countries have confronted shocks of a very different nature than the ones faced by LAIA members, as indicated by the fact that the nominal value of these countries' exports has decreased since 1980 .

In general, then, the evidence presented in this subsection seems to indicate that a sustained increase in Latin American exports - particularly of non-traditional products - - in the present circumstances will depend more on these nations' ability to diversify their exportable output and to penetrate industrialized countries' markets than on the deepening of intraregional trade agreements. However, the achievement of this goal will require not only a more transparent trade regime in the Latin American countries, but also a significant decline in the protectionist sentiments prevailing in the developed nations. To both of these issues we turn in the following section.

\section{v. Protectionism and the Future Evolution of Latin America's International Irade}

As noted in Section II, after approximately three decades of inward oriented policies, in the mid-1970s a number of Latin American countries started to move towards more outward oriented trade regimes, abandoning the idea of extending the import substitution process to a regional level. Although this trend towards greater openness occurred at different speeds, . 
it involved a large number of countries. Edwards (1988a), for example, reports data on average tariffs that clearly show that several countries in the region went through nontrivial trade liberalizations up to the early 1980s. However, the debt crisis and the need to reduce imports very fast resulted in a dramatic reversal of that tendency. As already mentioned in the preceding sections, in the mid-1980s in almost every country the degree of protectionism exceeds that of the beginning of the decade.

Although there is some debate on how desirable it is for the developing nations to move towards free trade, there is wide agreement that the Latin American nations should implement more transparent and non-discriminatory outward oriented regimes. Only in this way will efficiency increase and the volume of international trade, and especially exports, will grow fast enough. In fact, Mexico is already energetically moving in that direction. Tariffs, of course, constitute only one form of protection, and countries in fact use a large number of other mechanisms, generally known as nontariff barriers, to introduce de facto wedges between domestic and world prices. Nontariff barriers can take many different forms ranging from prior-deposits to outright quotas. The history of nontariff barriers in Latin America is long and generalized. Thus, in order for the region's volume of trade - - both intraregional and with the rest of the world -. to experience a significant increase both tariffs and the wide variety of NTBs should be drastically reduced. Multiple exchange rates are another mechanism used quite extensively by the Latin American nations to obstruct trade flows. Interestingly enough, intraregional trade agreements, and even the studies on NTBs, have not focused on this protective tool. At this point a number of countries in the region in fact do have multiple rates. 
The lack of reliable data on NTBs has generally frustrated analysts that have tried to assess with some degree of rigor the extent of protection in the developing world. For this reason in a recent massive cross country study undertaken at the World Bank, an effort to construct subjective "indexes of liberalization" was made. These indexes are supposed to capture the extent of trade impediments, including tariffs and other NTBs. They are subjective, in the sense that they don't combine actual objective measures. Although there are some shortcomings related to this subjectivity, including the nonverifiability and noncomparability across countries, their construction has been extremely useful, helping understand the evolution of "true protectionism" in some of these countries. For the five Latin American nations included among the 18 countries covered by the study, the indexes reflect both the protectionist history of these countries, as well as the efforts toward non-discriminatory liberalization implemented in the late 1970s and early 1980s (see Michaely, Papageorgiou and Choksi, 1986).

Unfortunately the data available on NTBs in the developing countries, and in particular in Latin America, are exceedingly sketchy. However, a recent study by ALADI (1984) provides some indication of the coverage of two forms of NTBs: outright prohibitions and prior import licenses. Table 18 summarizes these data. As can be seen from this table NTBs in Latin America constitute a serious obstacle and are as prevalent, if not more, than in the developed countries.

\section{V.1 Macroeconomic Diseguilibrium and Protectionist Pressures}

An issue that has not been sufficiently emphasized, especially by the supporters of an active integration process, is that Latin America's protectionist history has been intimately related to the region's macroeconomic instability. A common scenario observed again and again can be described as 
follows: at some point in time the authorities of a particular country decide to pursue a fiscal policy that is inconsistent with the chosen nominal exchange rate regime .- usually a pegged rate. Given the underdeveloped nature of the domestic capital market, the fiscal expansion is basically financed with domestic credit creation. As a result, there will be a loss of international reserves, domestic inflation will exceed world inflation, and the real exchange rate will become increasingly overvalued. In an effort to stop the drainage of reserves the authorities will usually respond by imposing exchange controls and by increasing the degree of restrictiveness of the existing trade impediments - tariffs will be hiked and QRs will be imposed. Naturally, as long as the ultimate causes of the macroeconomic disequilibrium - - that is, the inconsistent credit and fiscal policies -are not tackled, all the authorities will gain by imposing new trade restrictions is delay the need for corrective macroeconomic measures. The real exchange rate will become more overvalued, international reserves will continue to decline, and a black market for foreign exchange will emerge. At some point this disequilibrium situation will become unsustainable, and a stabilization program -- usually under the aegis of the IMF .. will be enacted. This program will usually consist of a significant nominal devaluation geared at correcting the overvaluation developed in the previous period, and of a contractionary macroeconomic policy.

Table 19 contains data on the evolution of import tariffs, exchange controls and capital controls in the period preceding 17 balance of payments crises in Latin America. The table reveals that in the great majority of the cases the crisis - - which always took the form of a major devaluation .. was preceded by an important piling up of exchange controls and restrictions. In some episodes, such as Colombia in 1962 and 1967, Ecuador 1961, 
and Peru in 1975, the intial conditions (two years prior to the crisis) were already extremely restrictive, and became even tighter as the erosion of reserves became severe and/or real exchange rate appreciation became more massive. In other cases, however -. Venezuela 1964 and Chile 1982, for example - the period preceding the devaluation was characterized by a fairly free environment, with little restrictions and no attempts by the authorities to impose any additional controls.

It is clear, then, that to the extent that the region does not implement serious and far-reaching structural reforms aimed at avoiding macroeconomic instability, we can expect the recurrence of periodic balance of payment crisis, with their concomitant negative effects on the trade regime and on the volume of trade - both intraregional and with the rest of the world.

\section{V.2 Protectionism in the Industrialized World}

As noted in subsection IV.2, the way in which Latin America's trade performs will not depend exclusively on the region's protectionist policies. Equally important, if not more, is what happens with trade impediments in the industrial nations.

While most Latin American nations have been going through almost heroic efforts aimed at improving their external balance, the industrial countries have been invaded with protectionist sentiments. In fact, in the past few years the industrial countries have used a series of nontariff mechanisms to impede a freer flow of Latin American goods. According to the GATT (1984), industrial countries currently use more than forty nontariff measures to impede international flows of commodities.

A few authors have dealt with the issue of nontariff barriers, analyzing the extent of these practices, their coverage across countries and 
products, and their evolution through time. For example, in a comprehensive recent study Nogues et al. (1986b) analyzed the use of nontariff barriers in 16 industrialized countries. For the purpose of their analysis they defined the following practices as nontariff barriers: prohibitions, quotas, discretionary import authorization, conditional import authorizations, "voluntary" export restraints, variable levies, minimum price systems, "voluntary" price restraints, tariff-quotas, seasonal tariffs, price and volume investigations, and antidumping and countervailing duties. Their analysis suggests that the coverage of this type of impediments is quite broad, affecting more than one-fourth of all these countries imports, with textiles being the industry most severely affected.

An important question is whether imports from all countries or regions are affected in the same way by the NTBs. Nogues et. al. found that this is not the case; Imports from the developing world are more severely affected by this type of "semi-disguised" protectionism than those from the industrialized world. A study by ECLA/CEPAL (1986e), confirmed this discriminatory trend. It found that the NTBs of industrialized countries, particularly those of the EEC, discriminate strongly against the exports coming from Latin American LDCs. Table 20 provides a summary of these findings. Once the effects of the NTBs are taken into account the degree of protection the industrialized countries grant to some product can be quite remarkable. Edwards (1988a), for instance, provides estimates of the total average rate of protection to which some Argentinian and Brazilian exports to the EEC, Japan and the U.S. were subject in 1980. These figures are in many ways staggering, indicating that in many cases the NTBs more than double the tariff protection. 
What is even more serious is that the existing evidence clearly indicates a slow but steady increase in the degree of coverage of the NTBs. For example, Nogues et al. (1986a) found that the NTBs coverage for all goods in the 16 industrial countries increased by 1.5 percentage points between 1981 and 1983. To the extent that these NTBs increase, or even if they are maintained at their current level, it will become very difficult if not plainly impossible, for the Latin American countries to continue to increase their exports at the rate required to solve the current debt crisis. While the main responsibility for increasing exports rests with the Latin American countries, their efforts, no matter how serious, can be easily frustrated by the protectionist policies of the industrialized world.

\section{The Prospects for Intraregional Trade and the Debt Crisis}

Recently, some authors have sustained that the adverse external conditions faced by Latin American countries in the aftermath of the debt crisis are the appropriate ones for an intensification of the integration process in the region. They argue that preferential reductions in tariffs coupled with an effective "desdollarization" of intraregional payments -. basically achieved through clearing house-type arrangements -. will revitalize intrareglonal flows of trade. In fact, in a recent study that analyzed the future prospects of the integration process in Latin America ECLA/CEPAL (1986d) postulated that the adoption of these types of measures would be translated in a sustained increase in the growth rate of intraregional trade flows. Specifically, the projections that constituted the benchmark of that study assumed that as a consequence of those measures the value of intraregional trade would grow at an annual rate of 16 percent in the following years. Table 21 reproduces these projections and shows how, under those 
assumptions, the share of intra-LAIA imports would increase from 15.9 percent in 1984 to 18.68 in 1990 and to 22.28 in 1994.

The evidence presented in this paper indicates that both the recommendations and the projected scenario implied by such proposals are fairly unrealistic. Although there is agreement that the Latin American countries should implement significant reductions in their protective structures and adopt more outward oriented policies, there is no justification for the presumption that the efficacy of these measures will be enhanced by restricting them to the regional market. Moreover, the LAFTA and the Andean Group experiences have shown the significant costs involved and the meager results achieved by regional liberalizations arrangements based on multilateral negotiations of the type that would be required, for example, to "de-dollarize" intraregional payments. On the other hand, the analysis in Sections III and IV have shown that the recent increase in Latin American exports of manufactures have been absorbed mostly by OECD nations. This in spite of the protectionist trends of these countries. Furthermore, the increase experienced by the aggregate share of intraregional imports during the same period was basically a consequence of the adjustment process. The adoption of a partial and discriminatory liberalization of regional imports will surely not be translated in a significant increase in that share in the current context.

In this sense, then, there does not seem to exist any solid basis for advocating the return to a more regulatory approach to commercial integration in Latin America. As noted before, the resumption of growth within the region will mainly depend on the design of a satisfactory solution to the debt problem, on the eradication of trade discriminatory practices in industrialized nations and on the extent to which each Latin 
American country decides to implement profound structural reforms aimed at avoiding macroeconomic instability and at achieving a less unbiased and intricate trade regime. Only if decisive steps in these directions are taken, the aggregate volume of imports and exports will grow, and it would be reasonable to expect a significant and sustained increase in intraregional trade within the pragmatic framework of the LAIA agreement.

\section{Concluding Remarks}

In this paper we have analyzed in detafl the evolution of Latin America's international trade patterns. The results of the different attempts to implement commercial integration arrangements among these countries and the future prospects of intraregional trade have been discussed. In particular, we have tried to assess the role of intraregional trade in the structural adjustment process that the solution of the current crisis requires from Latin American nations.

In this sense, it was seen that most of the schemes designed to promote commercial integration within the region were initially perceived and advocated as an extension to the import substitution strategy adopted by most Latin American countries in the 1950 s and 1960s. However, we pointed out that these arrangements overlooked the basic inconsistency that exists between the ambitious goal of establishing a common market of a regional (LAFTA) or subregional (Andean Group) dimension and the need of each government to satisfy the demands of their highly protected and influential import competing sectors. It was as a consequence of this conflict that these schemes turned out to be incapable of promoting a significant turnaround in the volume and direction of intraregional trade. Moreover, it was noted that the relative success of the regional liberalization process carried out 
in the CACM was explained, precisely, by the initially weak position of these nations' import competing sectors.

It was also established that the dissatisfaction with the poor overall performance of these comprehensive integration schemes, together with the adoption of a more outward oriented strategy by most Latin American countries in the late 1970s, determined the replacement of LAFTA by the LAIA Treaty and the practical abandonment of negotiations within the Andean Group. However, before the results of the more pragmatic approach of the LAIA agreement - - mainly based on bilateral tariff negotiations -- could be reflected in the data, the whole region was shocked by the abrupt curtailment of foreign funds in 1982. It was shown that the common denominators of the region's adjustment process prompted by this drastic shock were an abrupt contraction in the level of imports -- sometimes resorting to outright protectionist measures --and a desperate effort to increase exports earnings -. which was achleved despite the low prices of these countries' primary exports.

The extensive analysis of aggregate and disaggregate data carried out in this paper reflected both the meager results of the initial integration attempts and the particular characteristics of the region's adjustment to the debt crisis. With respect to the first, it was not possible to detect any significant change in the OECD countries' share -- especially the U.S. share - - in Latin American imports during the 1970s. In particular, the region remained highly dependent on imports of manufactured goods -. mainly capital goods .. from the industrialized countries. On the other hand, we found that the major achievement of the integration arrangements in that decade was limited to the increase in the intraregional trade share of some manufactured products. Nevertheless, the overall increase in the volume of 
intraregional trade flows was not found to be significant during that period.

In turn, the analysis of the more recent evolution of Latin America's trade flows revealed some interesting patterns. We could determine that the increase in the share of intraregional imports in the years immediately following the debt crisis was due to an asymetric contraction in the demand for imports originated within the region. The temporary nature of this phenomenon was put in evidence by the increase in the proportion of imports coming from industrialized countries that accompanied the slight expansion of the region's imports in 1985 and 1986. Another interesting finding was the significant increase in Latin America's imports of primary products from the OECD nations and particularly from the U.S. Although this implied a relative loss of competitiveness in these countries' production of manufactured goods in favor of Latin America, the evidence showed that, for the LAIA members, the intraregional share of manufactured imports is still substantially smaller than that of the industrialized nations.

On the other hand, the data on exports revealed that the significant expansion of Latin American exports after the debt crisis was propelled by a large increase in the production of fuel and of exportable manufactures. Moreover, we could determine that the latter were basically absorbed by the OECD markets, in particular by the U.S. In fact, all those Latin American countries that achieved a substantial increase in manufactured exports in that period (Argentina, Brazil, Mexico, Venezuela and Chile) experienced a decline in the proportion of their exports directed to the regional market.

Overall, this evidence seemed to indicate that the Latin American markets possess a rather limited capacity to absorb a significant increase in regional exports; at least in the current context of restrained imports 
and generalized external disequilibria, It appears, then, that the success of the required expansion in Latin American exports will depend more on these countries' capacity to diversify their exportable output and to design innovative mechanisms to penetrate the markets of industrialized countries, than on a renewal of efforts towards a substantial deepening of any regional trade integration process.

Even if the previous conclusion may seem uncontroversial its implementation is not free of serious obstacles. As we have noted, the current Latin American trade and exchange rate regimes are characterized by a high level of import restrictions (tariffs, NTB's and multiple exchange rates) and periodic balance of payments crises propelled by acute macroeconomic disequilibria. A sustained increase in Latin America's exports will be highly unlikely without far-reaching structural reforms aimed at solving these problems. Such an increase in the region's exports would also be facilitated if a satisfactory solution to the debt problem is finally reached and if a half is being put on the current protectionist trend in industrialized countries.

If decisive actions in the above directions were taken, the existent schemes for coordinating intraregional trade (LAIA, CACM and even the Andean Group) would play a very useful, but only complementary, role. In effect, by improving the payments clearing mechanisms and granting bilateral preferences to the poorer countries these arrangements may facilitate the transition towards a more affluent and liberalized .. in a general sense -regional trade. However, the temptation to overestimate the potential effects of these discriminatory arrangements on the volume of intraregional 
trade must be resisted. A global solution to the current crisis depends crucially on the region's ability to avoid previous mistakes. 


\section{Footnotes}

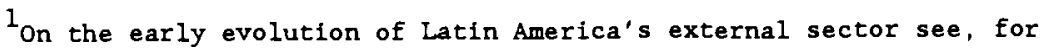
example, Furtado (1969). On Latin America and the great depression see Diaz Alejandro (1982, 1983), Maddison (1985) and Edwards (1988a). On the development strategies in Latin America, see Corbo (1986).

In what follows, the English and Spanish acronysms of the different organizations or agreements will be separated by a slash.

3 See, for example, the discussion in Furtado (1969).

${ }^{4}$ Edwards (1988a).

${ }^{5}$ As reflected in the works of Viner (1950), Meade (1955), Lipsey (1957) and Johnson (1960).

${ }^{6}$ These concessions were granted out of the NABALALC tariff nomenclature which is based on the Brussels tariff nomenclature and contains approximate1y 9200 items. The proportion of these tariff lines included in the "national list" of each country varied widely across LAFTA members.

${ }^{7}$ See Wionczek (1978), Cline (1983), Blejer (1984) and Fishlow (1984).

${ }^{8}$ The fifth member of the CACM, Costa Rica, joined the Treaty only in August of 1962. A detailed analysis of the factors that prompted the creation of CACM can be found in Delgado (1978).

${ }^{9}$ According to the 1965 "San Jose Protoco1", this action was supposed to be taken only under extremely unfavorable external conditions for the whole region.

${ }^{10}$ Although all share the characteristics of being primary producers and extremely dependent on external markets, there are wide differences in the economic size of these countries. Two groups can be clearly distinguished: the relatively more developed countries (Barbados, Guyana, Jamaica, 
Trinidad and Tobago) and the less developed ones (the seven Eastern Caribbean islands and Belize).

${ }^{11}$ These actions by Guyana and Jamaica were implicitly allowed by the CARICOM Treaty, because it did not establish concrete requirements for the elimination of domestic quantitative restrictions. See Chernick (1978).

${ }^{12}$ Venezuela joined the group in 1973 , while Chile withdrew from it in 1976 for reasons that will be addressed below.

${ }^{13}$ This deadline was later postponed to 1983 .

${ }^{14}$ See JUNAC (1982) for a detailed analysis of each of these programs.

${ }^{15}$ The need to develop an indicator of the "dual tariff-exchange rate" protection had its origins in this difficulty (see Morales 1983).

${ }^{16}$ An important issue refers to which external price index should be used to compute the evolution of the real value of imports and exports. The figure quoted above was calculated using the U.S. CPI. If instead the wholesale price index for the industrialized countries as a whole, as computed by the IMF, is used, Latin American imports declined by 49 on real terms between 1980 and 1985 .

${ }^{17}$ The decline of the trade ratic, however, is less marked than that of the imports ratio. The reason for this is that as a result of the adjustment program exports in most of these countries increased during the period.

${ }^{18}$ In Argentina, Chile, Venezuela, Peru, and El Salvador the U.S. share exhibited a slight increase between 1977 and 1982; in Brazil, Paraguay and Nicaragua there was somewhat of a decline during the same period. In the other countries the U.S. share fluctuated around a fairly stable value during 1977-81. 
${ }^{19}$ The distinction between primary and manufactured products made in these tables follows a classification criterion similar to that of Tables 8 and 9 . 


\section{Bibliography}

ALADI, 1984. "Elementos de Juicio para el Establecimiento de un Programa Para la Eliminacion de Restricciones no arancelarias," Caracas, Venezuela.

Balassa, B. and C. Balassa, 1984. "Industrial Protection in the Developing Countries," The World Economy, June, 179-96. , G.M. Bueno, P.P. Kuczynski and M.H. Simonsen, 1986. Toward

Renewed Economic Growth in Latin America, Washington D.C.: Institute of International Economics.

Blejer, M., 1984. "Economic Integration: An Analytical Overview" in

Economic and Social Progress in Latin America, Interamerican Development Bank.

Brock, P., 1987. "The Collapse of Intraregional Trade in the Central American Common Market: 1980-1987," unpublished ms., Duke University. Calvo, G., 1986. "Fractured Liberalism: Argentina Under Martinez de Hoz," Economic Development and Cultural Change; April.

Carvalho, J. and C. Haddad, 1981. "Foreign Trade Strategies and Employment in Brazil" in A.O. Kraeger et al. (eds.) Trade and Employment in Developing Countries, Chicago: U. of Chicago Press. CEPAL, 1985. Origen y Destino del Comercio Exterior de los Paises de la Asociacion Latinoamericana de Integracion y del Mercado Comun

Centroamericano, Cuadernos Estadisticos de la Cepal 9, Santiago, Chile. , 1986a. Anuario Estadistico de la Cepal, Santiago, Chile. , 1986b. "Origen y Destino del Comercio Exterior en 1983," Santiago, Chile, 28 August, 1986. 
, 1986c. "Reorientacion del Comercio Exterior de Productos

Basicos Hacia America Latina," Santiago, Chile, 25 June, 1986.

, 1986d. "Cooperacion Comercial y Negociaciones Regionales,"

Santiago, Chile, 28 July, 1986.

, 1986e. "Relaciones Economicas Internacionales y Cooperacion de

America Latina y el Caribe," Santiago, Chile, May, 1986.

, 1986f. "Banco de Datos Sobre Inversiones Extranjeras Directa en

America Latina y el Caribe," September, 1986.

. 1986g. "El Proteccionismo de los Paises Industrializados:

Estrategias Regionales de Negociacion y Defensa," Santiago, April.

, 1987. "Origen y Destino del Comercio Exterior en 1984,"

Santiago, Chile, Mar. 20.

Chernick, S., 1978. The Commonwealth Caribbean, Johns Hopkins University Press.

Cline, W., 1983. "Estrategia de las Negociaciones para la Integracion

Latinoamericana," in E. Conesa (ed.), Terminos de Intercambio y Tarifa

Optima en America Latina, Argentina, INTAL.

, 1985. Imports of Manufactures from Developing Countries:

Performance and Prospects for Market Access, Washington D.C.: Brookings Institution.

Corbo, V., 1985. "Chilean Economic Policy and International Economic

Relations Since 1970" in G.M. Walton (ed.) The National Economic Policies

of Chile, Greenwich CT: JAI Press.

, 1986. "Problems, Development Theory and Strategies of Latin

America," DRD Working Paper No. 190, The World Bank.

Cuddington, J., 1986. "Capital Flight from the Developing Countries,"

Unpublished Paper, The World Bank. 
Delgado, Enrique, 1978. "Institutional Evolution of the Central American Common Market and the Principle of Balanced Development," in W. Cline and E. Delgado (eds.), Economic Integration in Central America, Washington, DC: Brookings Institution.

Diaz-Alejandro, C.F., 1976. Colombia, New York: Columbia U. Press. , 1982. "Latin America in Depression, 1929-1939" in M. Gersovitz

et al. (eds.) The Theory and Experience of Economic Development, London: Allen \& Unwin. , 1983. "Stories of the 1930s for the 1980s" in P. Aspe Armella, et al. (eds.) Financial Policies and the World Capital Market, Chicago: U. of Chicago Press.

Dornbusch, R., 1986a. "Multiple Exchange Rates for Commercial Transactions" in S. Edwards and L. Ahamed (eds.) Economic Adjustment and Exchange Rates in Developing Countries, Chicago: U. of Chicago Press. , 1986b. "Special Exchange Rates for Capital Account

Transactions," World Bank Economic Review, September, 3-34. Edwards, S., 1983. "The External Sector in Colombia," Paper prepared for The World Bank.

, 1984. The Order of Liberalization of the External Sector in

Developing Countries, " Princeton Essays in International Finance No. 156. 1985. "Stabilization with Liberalization: An Evaluation of Ten

Years of Chile's Experience With Free Market Policies, 1973-1983," Economic Development and Cultural Change, January. 1988a. "The U.S. and Foreign Competition in Latin America," in M. Feldstein (ed.), The U,S, and the World Economy. Chicago: University of Chicago Press. 
, 1988b. "Exchange Controls, Devaluations and Real Exchange

Rates: The Latin American Experience," Economic Development and Cu1tural Change.

, 1988c. Exchange Rate Misalignment in Developing Countries.

Baltimore: Johns Hopkins University Press.

1988d. "Structural Adjustment Policies in Highly Indebted

Countries," in J. Sachs (ed.), The Developing Countries Debt: General

Studies. Chicago: University of Chicago Press.

- 1989. Real Exchange Rates. Devaluation and Adjustment:

Exchange Rate Policy in Developing Countries, forthcoming, MIT Press.

Edwards, S. and L. Ahamed (eds.), 1986. Economic Adjustment and Exchange

Rates in Developing Countries, Chicago: U. of Chicago Press.

Edwards, S. and A. Cox-Edwards, 1987. Monetarism and Liberalization: The

Chilean Experiment, Cambridge, MA: Ballinger Publishing Co.

Edwards, S. and F. Ng, 1985. "Trends in Real Exchange Rate Behavior in

Selected Developing Countries," CPD Working Paper, The World Bank.

Evans, P.B., 1986. "State, Capital, and the Transformation of Dependence:

The Brazilian Computer Case," World Development, 191-800.

Fishlow, A., 1984. "Reciprocal Trade Growth: The Latin American

Integration Experience," in M. Syrquin, L. Taylor and L. Westphal (eds.),

Economic Structure and Performance, Academic Press.

Furtado, C., 1969. La Econemla Latinosmericana, Santiago, Ed.

Universitaria.

GATT, 1984. "Report of the Group of Quantitative Restrictions and Other Non

Tariff Barriers," Geneva.

Hanson, J, and J. de Melo, 1985. "External Shocks, Financial Reforms, and

Stabilization Attempts in Uruguay during 1974-1983," World Development, 
August, $134-46$.

INTAL, The Latin American Integration Process (Various Issues),

InterAmerican Development Bank, Washington, DC.

International Monetary Fund, International Financial Statistics (Various Issues) Washington, DC. , Directions of Trade Statistics (Various Issues) Washington, DC.

Johnson, H., 1965. "An Economic Theory of Protectionism, Tariff Bargaining, and the Formation of Customs Unions," Journal of Political Economy, v. 73, April.

Jones, C.D., 1983. "Visible Imports Subject to Restraint," Government Economic Services WP No. 62 .

JUNAC, 1982. "La Programacion Industrial en el Grupo Andino," Lima, Peru. Krueger, A.0., 1980. Trade and Employment in Developing Countries, Vol. I, Chicago: U. of Chicago Press. , 1983. Trade and Employment in Developing Countries: Synthesis and Conclusions, Chicago: U. of Chicago Press.

Leamer, E.E., 1984. Sources of International Comparative Advantage, Cambridge: MIT Press.

Leamer, E. and R. Stern, 1973. Quantftative International Economics, Boston: Bycon Press.

Lipsey, R., 1957. "The Theory of Customs Unions, Trade Diversion and Welfare," Economica, February.

Maddison, A., 1985. Two Crises: Lafin America and Asia, 1929-38 and 19731983, Paris: OECD.

Meade, J., 1955. The Theory of Customs Unions, Amsterdam: North Holland Publishing Co. 
Michaely, M., D. Papageorgiou and A. Choksi "The Phasing of A Trade Liberalization Policy: Preliminary Evidence," Paper Presented at AEA Meeting, New Orleans.

Morales, J.A., 1983. "Problemas del Arancel Externo Comun: El Caso del Grupo Andino," CLADS Discussion Paper \#58, Boston University. Nogues, J., A. Olechowski and L.A. Winters, 1986a. "The Extent of Non Tariff Barriers to Imports of Developing Countries," World Bank Staff Working Paper 789. , 1986b. "The Extent of Non Tariff Barriers to Industrial

Countries' Imports," The World Bank Economic Review (September): 181-199. Nugent, J., 1974. Economic Integration in Central America, Johns Hopkins University Press.

Pfefferman, G., 1985. "Overvalued Exchange Rates and Development," Einance and Development, 22 (March) 17-19.

Prebisch, R., 1984. "Five Stages in My Thinking on Development" in G.M.

Meier and D. Seers (eds.) Ploneers in Development, Oxford: Oxford U. Press.

Rodriguez-Mendoza, M., 1986. "Latin America and the U.S. Trade and Tariff Act," Journal of World Trade Law, February, 47-60.

Thomas, V., 1986. Iinkine Macroeconomic and Agricultural Policies for Adjustment With Growth, Baltimore: Johns Hopkins University Press. Viner, J., 1950, The Customs Union Issue, New York: Carnegie Endowment for International Peace.

Wionczek, M., 1978. "Can the Broken Humpty-Dumpty Be Put Together Again and by Whom?" World Development, June.

World Bank, 1986. World Development Report, Washington, D.C. World Currency Yearbook (Various Issues). 

TABLE 1

LAFTA: Intraregional Exports and Preferences Granted $1962-1980$

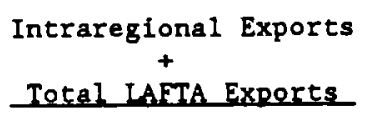

1962

1963

1964

1965

1966

1967

1968

1969

1970

1971

1972

1973

1974

1975

1976

1977

1978

1979

1980

\begin{abstract}
Total Number of Concessions Granted On "National Lists"
\end{abstract}

4,274

7,593

8,248

8,474

9,054

9,363

10,382

10,869

11,017

11,042

11,079

11,110

11,157

11,165

11,164

11,173

11,238

11,249

11,252

Source: INTAL - The Latin American Integration Process (1976, 1979-80) 


\section{TABLE 2}

Intraregional Exports in the Central American Common Market (Selected Years)

\begin{tabular}{lr} 
Intraregional Exports \\
$\begin{array}{l}+ \\
\text { Total CACM Exports }\end{array}$ \\
\hline \\
1960 & 7.5 \\
1961 & 7.8 \\
1968 & 24.2 \\
1971 & 23.4 \\
1974 & 25.6 \\
1978 & 21.4 \\
1980 & 23.1 \\
1983 & 20.4
\end{tabular}

Source: Cline (1983). 
TABLE 3

Evolution of Imports and Exports in Selected

Latin American Countries: 1970-1985

(Militions \$U.S.)

Imports

Country $\quad 1970 \quad 1975 \quad 1980 \quad 1982 \quad 1985$

Argentina $\quad 1694 \quad 3946 \quad 10541 \quad 5337 \quad 3814$

$\begin{array}{lllllllllll}\text { Bolivia } & 159 & 575 & 678 & 578 & 582 & 190 & 444 & 942 & 828 & 673\end{array}$

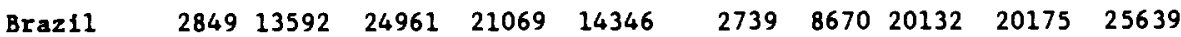

$\begin{array}{lllllllllll}\text { Chile } & 941 & 1338 & 5123 & 3528 & 2742 & 1248 & 1552 & 4671 & 3710 & 3797\end{array}$

$\begin{array}{lllllllllll}\text { Colombia } & 843 & 1495 & 4663 & 5478 & 4141 & 736 & 1465 & 3945 & 3095 & 3551\end{array}$

$\begin{array}{lllllllllll}\text { Costa RLca } & 317 & 694 & 1540 & 889 & 1098 & 231 & 493 & 1002 & 870 & 962\end{array}$

$\begin{array}{lllllllllll}\text { Dom. Rep. } & 304 & 889 & 1640 & 1444 & 1487 & 249 & 894 & 961 & 767 & 735\end{array}$

$\begin{array}{lllllllllll}\text { Ecuador } & 274 & 987 & 2253 & 1989 & 1606 & 190 & 974 & 2481 & 2128 & 2905\end{array}$

$\begin{array}{lllllllllll}\text { Guatemala } & 284 & 733 & 1598 & 1388 & 1175 & 298 & 641 & 1557 & 1153 & 1140\end{array}$

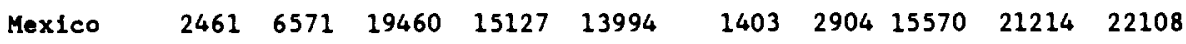

$\begin{array}{lllllllllll}\text { Panama } & 357 & 892 & 1449 & 1569 & 1423 & 110 & 286 & 361 & 375 & 335\end{array}$

$\begin{array}{lllllllllll}\text { Peru } & 622 & 2551 & 2500 & 3601 & 1835 & 1034 & 1291 & 3898 & 3293 & 2966\end{array}$

$\begin{array}{lllllllllll}\text { Uruguay } & 231 & 557 & 1680 & 1110 & 788 & 233 & 384 & 1059 & 1023 & 855\end{array}$

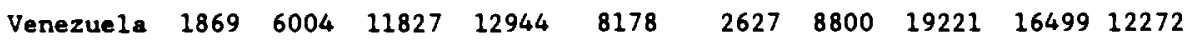

Source: International Financial statistics. 
TABLE 4

Openness Index in Selected Latin American Countries:

\begin{tabular}{lccccc} 
& \multicolumn{5}{c}{$1965-1985^{*}$} \\
& 1965 & 1970 & 1975 & 1980 & $\frac{1985}{18.4^{\mathrm{a}}}$ \\
Argentina & - & - & 33.8 & 12.8 & $14.6^{\mathrm{b}}$ \\
Bolivia & 40.2 & 33.6 & 41.4 & 30.9 & $20.2 \mathrm{~b}$ \\
Brazil & 12.5 & 13.7 & 19.3 & 21.0 & 38.0 \\
Chile & 18.6 & 29.2 & 31.1 & 35.5 & 21.0 \\
Colombia & 22.0 & 22.5 & 23.8 & 27.2 & 56.8 \\
Costa Rica & 48.9 & 55.6 & 60.5 & 52.6 & 47.7 \\
Dom. Republic & 23.3 & 37.2 & 49.5 & 39.2 & $33.4^{\mathrm{b}}$ \\
Ecuador & 28.6 & 33.1 & 45.5 & 40.3 & $25.6^{\mathrm{b}}$ \\
Guatemala & 31.3 & 30.6 & 37.1 & 40.0 & 13.3 \\
Mexico & 13.0 & 10.9 & 10.81 & 18.9 & 37.4 \\
Panama & 43.6 & 45.7 & 64.0 & 50.8 & $31.6^{\mathrm{b}}$ \\
Peru & 33.0 & 26.6 & 31.4 & 41.9 & $34.8^{\mathrm{b}}$ \\
Uruguay & 34.8 & 19.3 & 29.3 & 29.0 & $51.6^{\mathrm{b}}$ \\
Venezuela & 45.2 & 38.3 & 53.7 & 52.4 &
\end{tabular}

* This index was constructed as the ratio of total trade (imports plus exports) to GDP.

$$
\begin{gathered}
a_{1983} \\
b_{1984}
\end{gathered}
$$

Source: Constructed from data from Directions of Trade, International Monetary Fund. 
TABLE 5

Imports By Origin in Selected Latin American Countries

$1977-1986$ (percent)

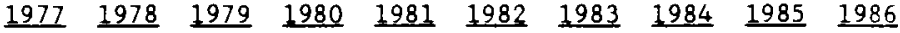

Argentina

- Industrialized

$\begin{array}{llllllllll}65.8 & 67.5 & 65.0 & 68.2 & 69.1 & 62.8 & 62.9 & 58.1 & 60.4 & 63.1\end{array}$

- Latin America

$\begin{array}{llllllllll}23.3 & 21.0 & 23.6 & 21.4 & 21.1 & 30.0 & 32.6 & 36.5 & 34.6 & 31.5\end{array}$

\& Caribbean

- Rest

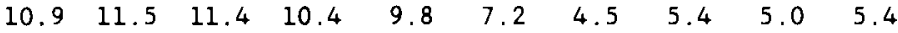

Bolivia

- Industrialized

$\begin{array}{llllllllll}58.7 & 66.2 & 61.0 & 61.1 & 57.9 & 59.8 & 55.7 & 45.7 & 46.7 & 38.5\end{array}$

- Latin America

$\begin{array}{llllllllll}31.9 & 23.6 & 28.2 & 28.2 & 32.8 & 32.8 & 41.5 & 47.8 & 48.8 & 57.0\end{array}$

Caribbean

- Rest

$\begin{array}{llllllllll}9.4 & 10.2 & 10.8 & 10.7 & 9.3 & 7.4 & 2.8 & 6.5 & 4.5 & 4.5\end{array}$

Brazi1

- Industrialized

$\begin{array}{llllllllll}53.4 & 56.1 & 48.9 & 46.6 & 41.8 & 38.6 & 38.3 & 39.7 & 45.1 & 61.3\end{array}$

- Latin America

$\begin{array}{llllllllll}10.5 & 10.1 & 11.8 & 12.5 & 14.6 & 17.4 & 14.8 & 15.8 & 12.5 & 9.7\end{array}$

$\&$ Caribbean

- Rest

$\begin{array}{llllllllll}36.1 & 33.8 & 39.3 & 40.9 & 43.6 & 44.0 & 46.9 & 44.5 & 42.4 & 29.0\end{array}$

Chile

- Industrialized

$\begin{array}{llllllllll}53.4 & 57.4 & 54.2 & 60.1 & 60.7 & 57.0 & 50.1 & 52.2 & 51.2 & 56.3\end{array}$

- Latin America

$\begin{array}{llllllllll}28.0 & 24.3 & 22.1 & 27.1 & 25.6 & 23.5 & 29.9 & 28.1 & 26.5 & 24.9\end{array}$

$\&$ Caribbean

- Rest

$\begin{array}{llllllllll}18.6 & 18.3 & 23.7 & 12.8 & 13.7 & 19.5 & 20.0 & 19.7 & 22.3 & 18.8\end{array}$

Colombia

- Industrialized

- Latin America

$\begin{array}{llllllllll}76.2 & 75.7 & 75.4 & 75.3 & 70.7 & 70.4 & 70.7 & 71.6 & 72.8 & 77.5\end{array}$

$\begin{array}{llllllllll}15.1 & 17.8 & 17.8 & 20.5 & 26.1 & 26.8 & 25.4 & 25.3 & 24.3 & 19.2\end{array}$

\& Caribbean

- Rest

$\begin{array}{llllllllll}8.7 & 6.5 & 6.8 & 4.2 & 3.2 & 2.8 & 3.9 & 3.1 & 2.9 & 3.3\end{array}$

Costa Rica

- Industrialized

- Latin America

\& Caribbean

- Rest

$\begin{array}{rrrrrrrrrr}65.6 & 68.0 & 62.4 & 63.7 & 60.9 & 56.3 & 58.8 & 61.7 & 63.1 & 71.3 \\ 29.3 & 29.3 & 31.8 & 34.2 & 36.8 & 40.5 & 38.7 & 34.8 & 33.0 & 23.5 \\ 5.1 & 2.7 & 5.8 & 2.1 & 2.3 & 3.2 & 2.5 & 3.5 & 3.9 & 5.2\end{array}$

Dominican Republic

- Industrialized

$\begin{array}{lllllllllll}69.6 & 69.1 & 65.9 & 67.3 & 61.6 & 58.3 & 55.2 & 50.8 & 54.3 & 48.1\end{array}$

- Latin America

$\begin{array}{llllllllll}28.7 & 28.5 & 31.8 & 30.0 & 36.4 & 39.7 & 42.7 & 46.9 & 42.8 & 43.3\end{array}$

\& Caribbean

- Rest

$1.7 \quad 2.4 \quad 2.3$

$2.7 \quad 0.2 \quad 0.2$

2,1

2.3

$2.9 \quad 8.6$

(continued) 
Table 5 (cont)

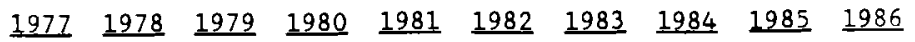

Ecuador

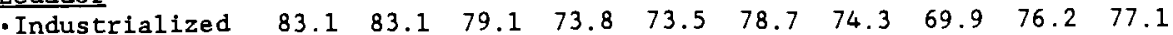

$\begin{array}{lllllllllll}\text { - Latin America } & 11.9 & 11.6 & 13.5 & 18.9 & 13.4 & 15.5 & 19.6 & 24.4 & 16.8 & 17.0\end{array}$

\& Caribbean

- Rest

$\begin{array}{llllllllll}5.0 & 5.3 & 7.4 & 7.3 & 13.1 & 5.8 & 6.1 & 5.7 & 7.0 & 5.9\end{array}$

Guatema 1a

- Industrialized

$\begin{array}{llllllllll}67.4 & 63.3 & 60.3 & 59.4 & 60.6 & 57.6 & 52.4 & 52.1 & 58.6 & 61.3\end{array}$

- Latin America $\begin{array}{llllllllll}28.5 & 34.1 & 35.3 & 37.3 & 35.8 & 39.5 & 45.3 & 44.9 & 37.9 & 34.9\end{array}$ \& Caribbean

- Rest

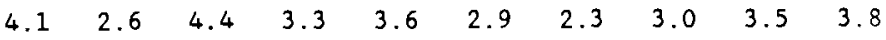

Mexico

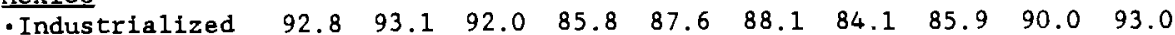

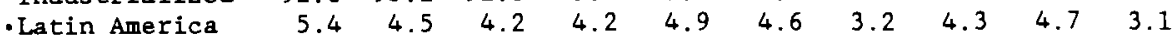
$\&$ Caribbean

- Rest

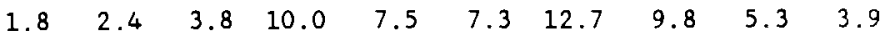

Panama

- Industrialized

$\begin{array}{llllllllll}47.1 & 51.1 & 49.2 & 49.6 & 51.1 & 53.6 & 51.3 & 52.0 & 53.5 & 54.5\end{array}$

- Latin America

\& Caribbean

- Rest

$\begin{array}{lllllllllll}24.1 & 25.3 & 24.4 & 19.3 & 28.6 & 33.3 & 33.9 & 43.0 & 41.7 & 12.3\end{array}$

$\begin{array}{llllllllll}28.8 & 23.6 & 26.4 & 31.1 & 20.3 & 13.1 & 14.8 & 5.0 & 4.8 & 33.2\end{array}$

Peru

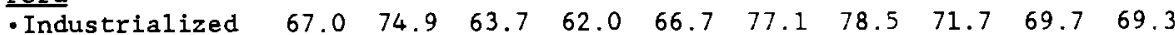

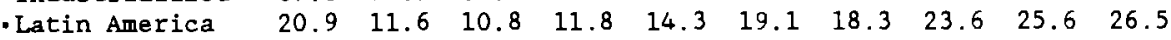

$\&$ Caribbean

- Rest

$\begin{array}{llllllllll}12.1 & 13.5 & 25.5 & 26.2 & 19.0 & 3.8 & 3.2 & 4.7 & 4.7 & 4.2\end{array}$

Uruguay

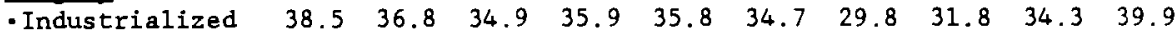

- Latin America

\& Caribbean

- Rest

$\begin{array}{llllllllll}29.4 & 29.3 & 38.2 & 37.6 & 45.7 & 41.8 & 44.3 & 37.2 & 38.7 & 43.2\end{array}$

$\begin{array}{llllllllll}32.1 & 33.9 & 26.9 & 26.5 & 18.5 & 23.5 & 25.9 & 31.0 & 27.0 & 16.9\end{array}$

Venezue la

$\begin{array}{lllllllllll}\text {-Industrialized } & 85.5 & 86.2 & 85.3 & 86.3 & 86.1 & 84.0 & 82.6 & 82.2 & 83.2 & 85.3\end{array}$

$\begin{array}{lllllllllll}\text { - Latin America } & 10.1 & 10.1 & 11.6 & 10.2 & 10.3 & 12.5 & 14.4 & 15.0 & 12.8 & 11.2\end{array}$ $\&$ Caribbean

- Rest

$\begin{array}{llllllllll}4.4 & 3.7 & 3.1 & 3.5 & 3.6 & 3.5 & 3.0 & 2.8 & 4.0 & 3.5\end{array}$

Source: Directions of Trade, International Monetary Fund. 
TABLE 6

Destination of Exports: 16 Latin Anerican Countries - 1970-1984*

(percent)

\begin{tabular}{|c|c|c|c|c|c|c|c|c|c|c|c|}
\hline & 1970 & 1975 & 1976 & 1977 & 1978 & 1979 & 1980 & 1981 & 1982 & 1983 & 1984 \\
\hline $\begin{array}{l}\text { Latin } \\
\text { America }\end{array}$ & 13.4 & 16.5 & 15.8 & 16.1 & 15.6 & 16.4 & 16.2 & 15.9 & 14.3 & 10.5 & 10.6 \\
\hline Caribb & ean & & & & & & & & & & \\
\hline - ALADI & 9.3 & 12.5 & 12.1 & 12.7 & 12.1 & 13.4 & 13.2 & 12.8 & 11.8 & 8.2 & 8.6 \\
\hline OECD & 75.0 & 63.6 & 66.1 & 66.4 & 67.5 & 66.2 & 63.6 & 58.4 & 62.8 & 69.0 & 71.1 \\
\hline - U.S. & 30.4 & 28.5 & 28.9 & 29.8 & 32.3 & 31.1 & 29.4 & 26.8 & 29.5 & 37.1 & 40.3 \\
\hline - Japan & 5.8 & 4.8 & 4.8 & 4.5 & 4.4 & 4.5 & 4.9 & 4.6 & 6.0 & 5.5 & 5.4 \\
\hline CAME & 2.5 & 5.2 & 4.9 & 4.6 & 3.9 & 3.3 & 4.6 & 6.1 & 4.3 & 4.5 & 3.8 \\
\hline $\begin{array}{l}\text { Rest of } \\
\text { Asia }\end{array}$ & 1.1 & 2.9 & 2.1 & 3.4 & 3.6 & 3.8 & 3.7 & 3.1 & 4.8 & 7.1 & 5.8 \\
\hline REST & 8.0 & 11.8 & 11.1 & 9.5 & 9.4 & 10.3 & 11.9 & 16.5 & 12.0 & 8.9 & 8.7 \\
\hline TOTAL & 100.0 & 100.0 & 100.0 & 100.0 & 100.0 & 100.0 & 100.0 & 100.0 & 100.0 & 100.0 & 100.0 \\
\hline
\end{tabular}

* The countries included here are Argentina, Bolivia, Brazil, Colombia, Costa Rica, Chile, Ecuador, El Salvador, Guatemala, Honduras, Mexico, Nicaragua, Paraguay, Peru, Uruguay and Venezuela.

Source: ECLA/CEPAL. 


\section{TABLE 7}

Sectoral Composition of Imports In

16 Latin American Countries: 1970-1984

Total Imports

0 . Foodstuffs and Live Animals

1. Beverages and Tobacco

2. Raw Nonfood, Except Fuel

3. Fuel and Related Products

4. O11, Grease \& Waxes of Sectoral origin

5. Chemicals

6. Manufactured

7. Machinery and Transport

8. Other Manufactured

9. Other

Total (Millions U.S.\$)

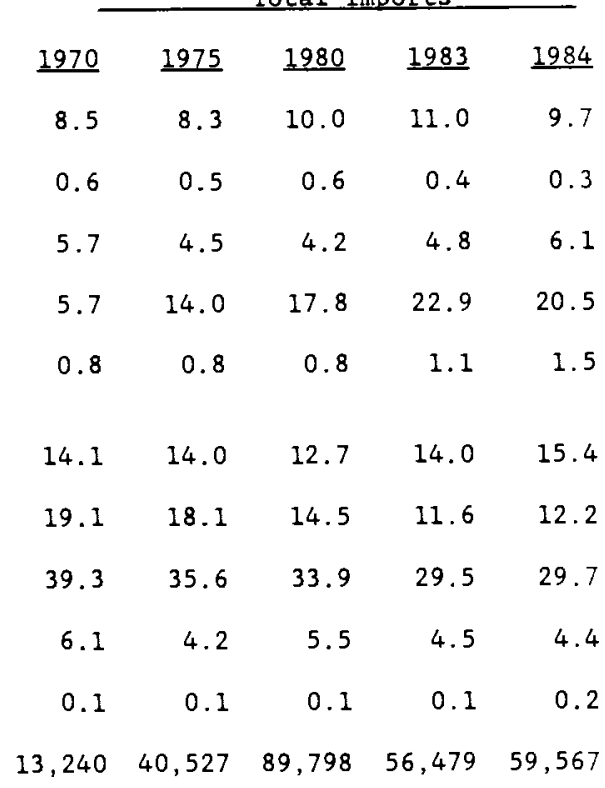

Source: ECLA/CEPAL. 
TABLE 8

Upper Middle Income Latin American Countries Imports of Manufactured and Primary Goods -. 1970-1984

\begin{tabular}{|c|c|c|c|c|c|c|c|c|c|}
\hline \multirow[b]{2}{*}{ Country } & \multirow[b]{2}{*}{ Year } & \multicolumn{4}{|c|}{ Manufactured Imports } & \multicolumn{4}{|c|}{ Primary Imports } \\
\hline & & $\begin{array}{l}\text { Total } \\
\text { U.S.S } \\
\end{array}$ & $\begin{array}{c}\text { L.A \& } \\
\text { Caribbean }\end{array}$ & U.S. & Japan & $\begin{array}{l}\text { Total } \\
\mathrm{U}, \mathrm{S}, \mathrm{S}\end{array}$ & $\begin{array}{c}\text { L.A. \& } \\
\text { Caribbean }\end{array}$ & $\underline{\mathrm{U} . \mathrm{S}}$ & Japan \\
\hline \multirow[t]{5}{*}{ Argentina } & 1970 & 1320.7 & 0.108 & 0.288 & 0.064 & 287.4 & 0.693 & 0.071 & 0.002 \\
\hline & 1975 & 2822.9 & 0.120 & 0.164 & 0.170 & 600.1 & 0.616 & 0.185 & 0.004 \\
\hline & 1980 & 8311.4 & 0.132 & 0.262 & 0.117 & 499.0 & 0.181 & 0.319 & 0.011 \\
\hline & 1983 & 3509.0 & 0.200 & 0.249 & 0.097 & 530.5 & 0.646 & 0.113 & 0.007 \\
\hline & 1984 & 3527.3 & 0.245 & 0.210 & 0.106 & 578.6 & 0.670 & 0.085 & 0.005 \\
\hline \multirow[t]{5}{*}{ Brazil } & 1970 & 2058.5 & 0.047 & 0.358 & 0.084 & 391.8 & 0.380 & 0.267 & 0.009 \\
\hline & 1975 & 8812.4 & 0.042 & 0.310 & 0.140 & 1209.3 & 0.243 & 0.381 & 0.019 \\
\hline & 1980 & 11659.7 & 0.093 & 0.320 & 0.099 & 3141.3 & 0.333 & 0.283 & 0.003 \\
\hline & 1983 & 6020.3 & 0.083 & 0.325 & 0.109 & 1857.7 & 0.252 & 0.323 & 0.004 \\
\hline & 1984 & 5233.6 & 0.106 & 0.299 & 0.115 & 1913.4 & 0.313 & 0.342 & 0.002 \\
\hline \multirow[t]{5}{*}{ Chile } & 1970 & 682.8 & 0.069 & 0.438 & 0.040 & 188.3 & 0.628 & 0.178 & 0.002 \\
\hline & 1975 & 875.8 & 0.160 & 0.344 & 0.085 & 353.8 & 0.418 & 0.383 & 0.005 \\
\hline & 1980 & 3097.6 & 0.156 & 0.289 & 0.124 & 1080.0 & 0.412 & 0.327 & 0.011 \\
\hline & 1983 & 1503.5 & 0.155 & 0.291 & 0.103 & 611.6 & 0.451 & 0.377 & 0.002 \\
\hline & 1984 & 1960.2 & 0.171 & 0.260 & 0.146 & 573.6 & 0.494 & 0.319 & 0.001 \\
\hline \multirow[t]{5}{*}{ Mexico } & 1970 & 2007.1 & 0.017 & 0.626 & 0.042 & 374.7 & 0.082 & 0.661 & 0.002 \\
\hline & 1975 & 4923.4 & 0.026 & 0.625 & 0.062 & 1286.1 & 0.191 & 0.657 & 0.001 \\
\hline & 1980 & 13898.3 & 0.042 & 0.644 & 0.064 & 3528.0 & 0.041 & 0.775 & 0.001 \\
\hline & 1983 & 7585.9 & 0.013 & 0.677 & 0.052 & 2816.7 & 0.029 & 0.876 & 0.001 \\
\hline & 1984 & 10666.0 & 0.016 & 0.678 & 0.060 & 3175.0 & 0.108 & 0.757 & 0.001 \\
\hline \multirow[t]{5}{*}{ Uruguay } & 1970 & 147.2 & 0.254 & 0.168 & 0.022 & 51.5 & 0.671 & 0.071 & 0.005 \\
\hline & 1975 & 264.6 & 0.298 & 0.136 & 0.044 & 90.7 & 0.463 & 0.181 & 0.006 \\
\hline & 1980 & 932.8 & 0.362 & 0.14 & 0.066 & 208.9 & 0.642 & 0.097 & 0.009 \\
\hline & 1983 & 323.9 & 0.361 & 0.134 & 0.046 & 99.4 & 0.655 & 0.087 & 0.002 \\
\hline & 1984 & 359.6 & 0.431 & 0.140 & 0.026 & 119.3 & 0.636 & 0.105 & 0.003 \\
\hline \multirow[t]{5}{*}{ Venezuela } & 1970 & 1597.5 & 0.034 & 0.47 & 0.092 & 281.3 & 0.079 & 0.549 & 0.014 \\
\hline & 1975 & 4871.4 & 0.052 & 0.483 & 0.090 & 879.6 & 0.098 & 0.515 & 0.012 \\
\hline & 1980 & 9871.7 & 0.071 & 0.472 & 0.097 & 2182.3 & 0.089 & 0.529 & 0.006 \\
\hline & 1983 & 4454.5 & 0.085 & 0.448 & 0.077 & 1514.1 & 0.21 & 0.542 & 0.001 \\
\hline & 1984 & 4912.2 & 0.093 & 0.475 & 0.068 & 1901.6 & 0.182 & 0.528 & 0.001 \\
\hline
\end{tabular}

Source: ECLA/CEPAL. 
TABLE 9

Latin American Middle Income Countries Imports of

Manufactured and Primary Goods - - 1970-1984

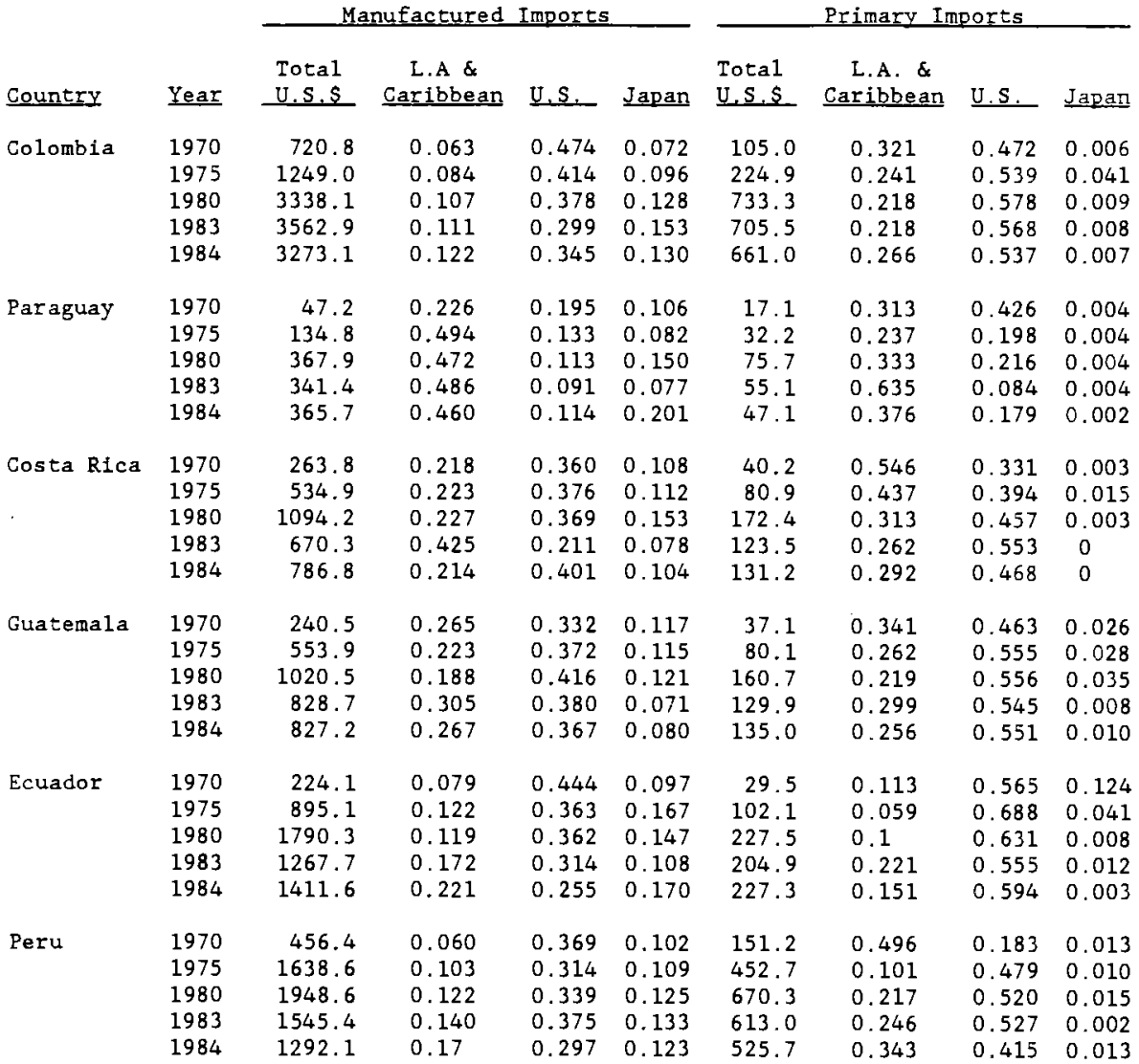

Source: ECLA/GEPAL. 

站
뭉ำ

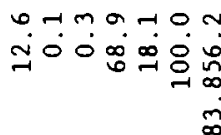

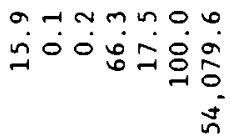

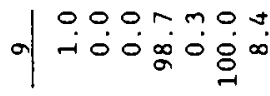
roOndor
Noonoom
toogoom
- 000000
-io àं
ब००

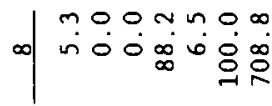
monanoa
ohntoom

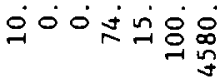
ง $00000-1$ 웅ㅇㅇㅇ
|
To00007
- 00 in $\infty 0 \infty$
NoOHnOm
०००ूल

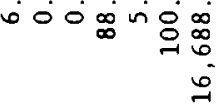

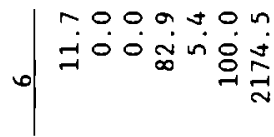

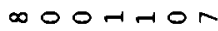
thrtoom
- $0 m \infty \infty 0 m$
우요용
लें0 표요

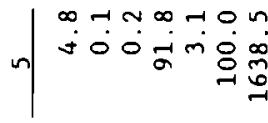
NN Nan 0 \%

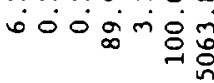
andoro in
a $-1=0.000$
No 0 in 0 i
$=00 \dot{\infty}-\dot{0} \underset{0}{\infty}$

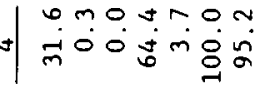
moontoo
nooneor
Noom mot

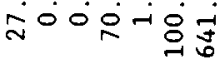
जे 0 กู०

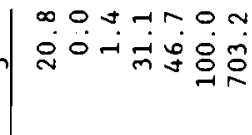
mioni
normmos
mom $\infty+0-1$

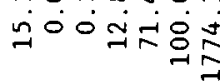
¿ 0 \%
Don-rom
No
우

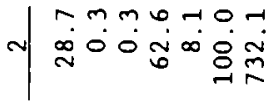
$\infty$ m n mon
-
am $\infty \leqslant 0 w$ ช 0 0

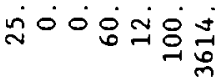
సं००

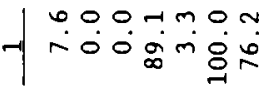
000 in mor
$m-n-\infty 0 a$
$000+60 N$
Nóg

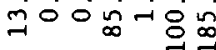

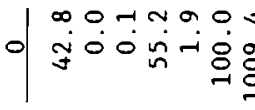
N- an o
H-
oartar a
กั०
लें0
कू
હ
क
$\Sigma$ 空
㲘

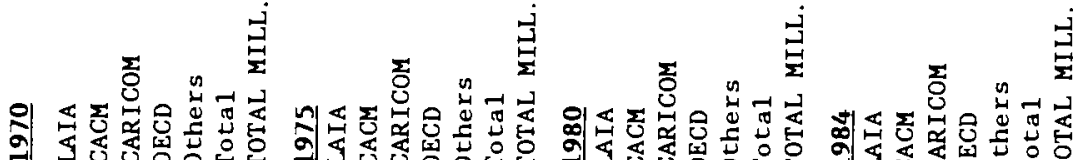 点 $\quad$ 岁

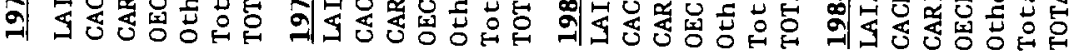




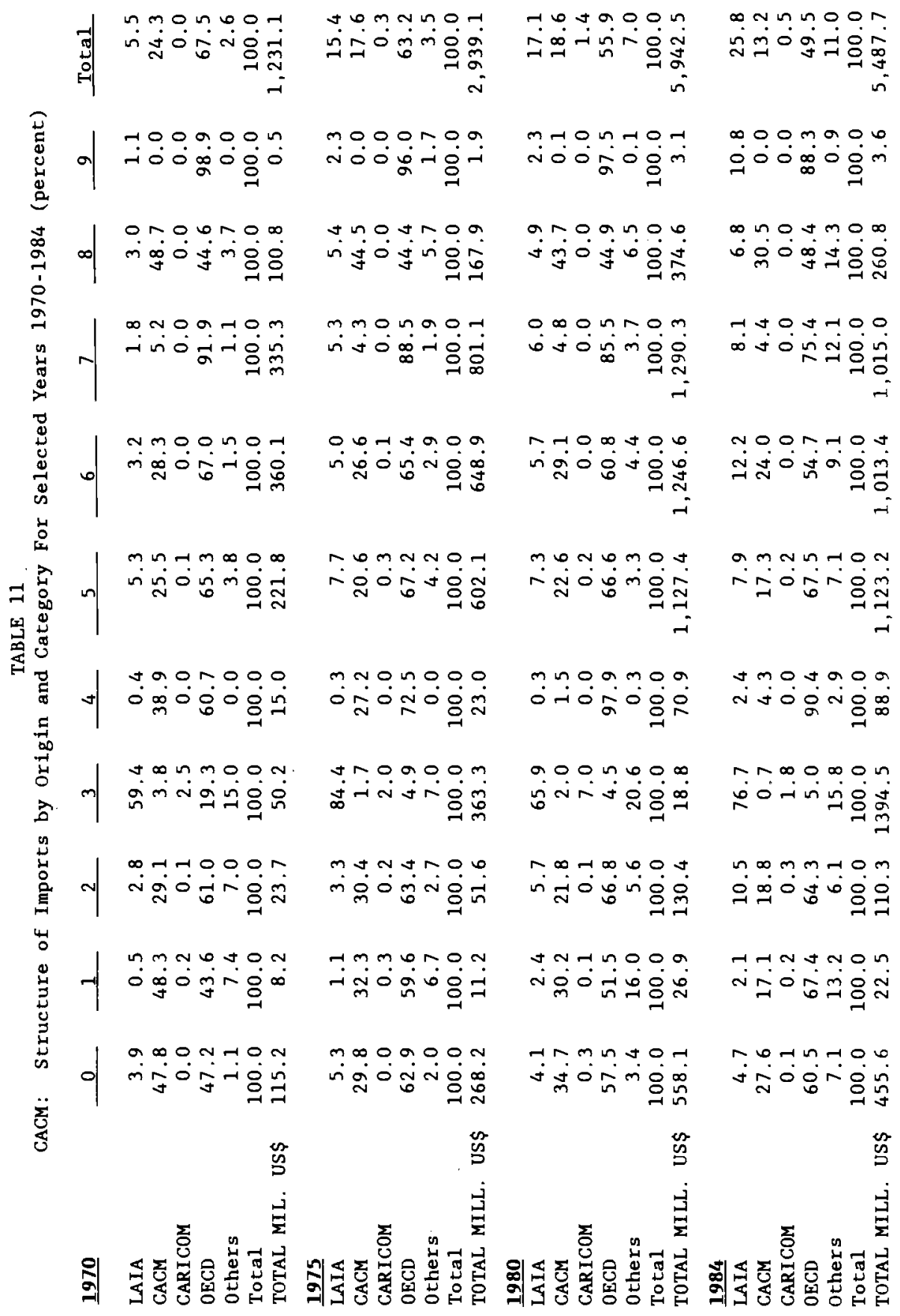




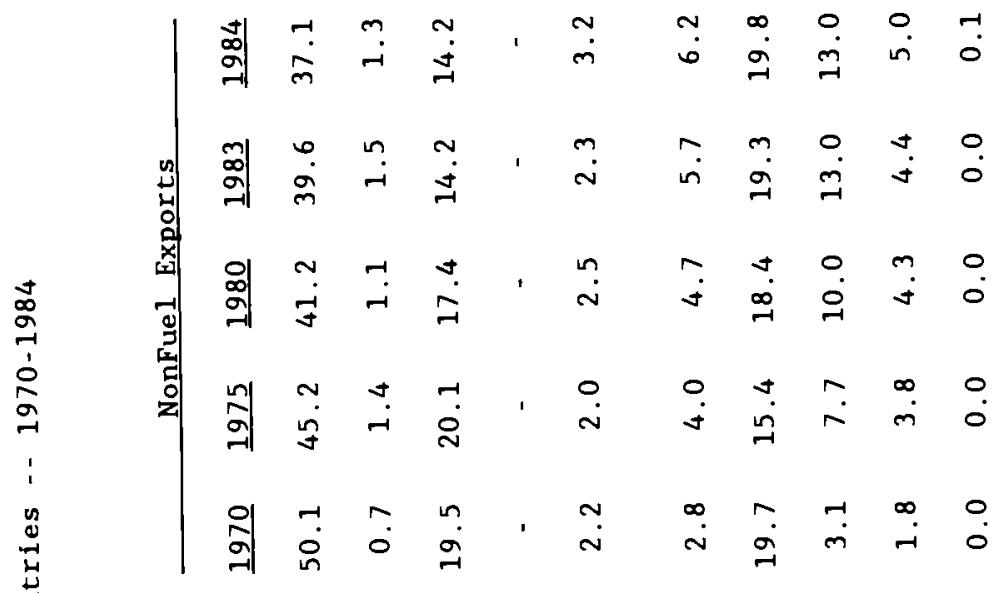

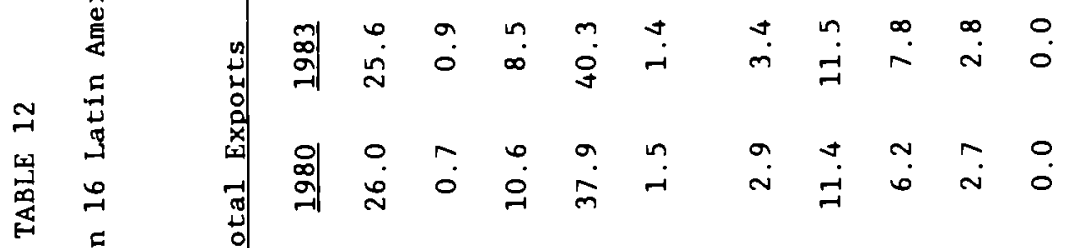

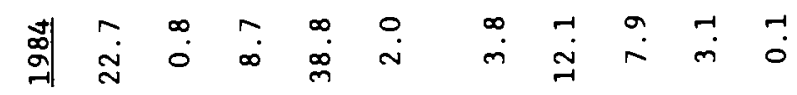

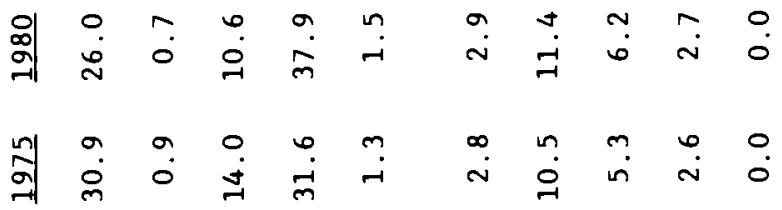

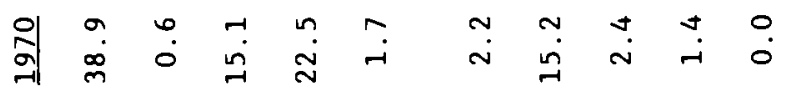

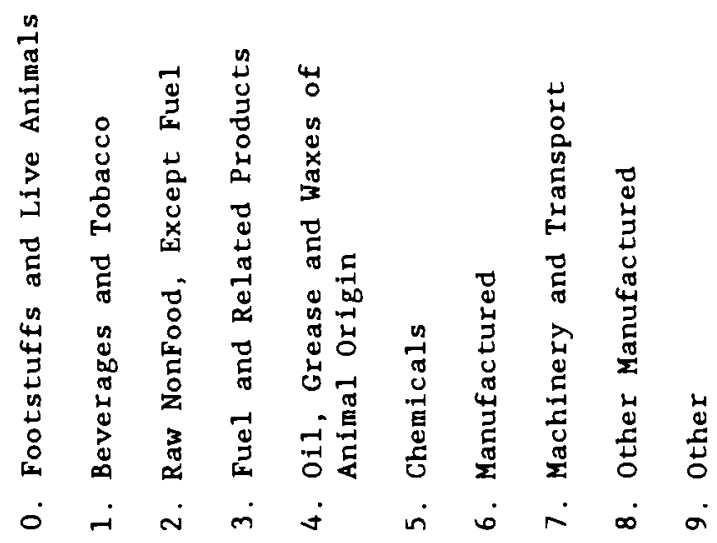


TABLE 13

Upper Middle Income Countries:

Exports of Manufactured and Primary Goods - 1970-1984

\begin{tabular}{|c|c|c|c|c|c|c|c|c|c|}
\hline \multirow[b]{2}{*}{ Country } & \multirow[b]{2}{*}{ Year } & \multicolumn{4}{|c|}{ Manufactured Exports } & \multicolumn{4}{|c|}{ Primary Exports } \\
\hline & & $\begin{array}{l}\text { Total } \\
\text { U.S.S } \\
\end{array}$ & $\begin{array}{c}\text { L.A \& } \\
\text { Caribbean }\end{array}$ & $\underline{U}, S_{1}$ & $\underline{\text { Japan }}$ & $\begin{array}{l}\text { Total } \\
\text { U.S.S } \\
\end{array}$ & $\begin{array}{c}\text { L.A. \& } \\
\text { Caribbean }\end{array}$ & $\underline{\text { U.S. }}$ & $\underline{\text { Japan }}$ \\
\hline \multirow[t]{5}{*}{ Argentina } & 1970 & 248.0 & 0.499 & 0.205 & 0.003 & 1517.2 & 0.160 & 0.070 & 0.070 \\
\hline & 1975 & 722.3 & 0.546 & 0.084 & 0.022 & 2223.0 & 0.170 & 0.060 & 0.050 \\
\hline & 1980 & 1995.3 & 0.415 & 0.155 & 0.042 & 5737.0 & 0.176 & 0.074 & 0.020 \\
\hline & 1983 & 1363.8 & 0.281 & 0.276 & 0.024 & 6136.1 & 0.094 & 0.050 & 0.054 \\
\hline & 1984 & 1473.9 & 0.322 & 0.248 & 0.032 & 6299.1 & 0.137 & 0.051 & 0.034 \\
\hline \multirow[t]{5}{*}{ Brazil } & 1970 & 368.5 & 0.403 & 0.169 & 0.040 & 2329.0 & 0.062 & 0.261 & 0.055 \\
\hline & 1975 & 2209.9 & 0.369 & 0.201 & 0.036 & 6068.0 & 0.051 & 0.137 & 0.096 \\
\hline & 1980 & 7546.7 & 0.377 & 0.182 & 0.038 & 11906.0 & 0.047 & 0.174 & 0.079 \\
\hline & 1983 & 8987.3 & 0.173 & 0.222 & 0.059 & 11465.3 & 0.042 & 0.15 & 0.079 \\
\hline & 1984 & 11685.9 & 0.188 & 0.358 & 0.050 & 13183.2 & 0.050 & 0.212 & 0.071 \\
\hline \multirow[t]{5}{*}{ Chile } & 1970 & 1104.1 & 0.143 & 0.137 & 0.074 & 214.7 & 0.196 & 0.133 & 0.306 \\
\hline & 1975 & 1180.4 & 0.204 & 0.069 & 0.081 & 454.0 & 0.305 & 0.133 & 0.202 \\
\hline & 1980 & 2807.0 & 0.244 & 0.129 & 0.041 & 1713.0 & 0.237 & 0.057 & 0.226 \\
\hline & 1983 & 2010.1 & 0.132 & 0.343 & 0.021 & 1548.8 & 0.119 & 0.159 & 0.182 \\
\hline & 1984 & 1776.8 & 0.184 & 0.269 & 0.067 & 1637.7 & 0.127 & 0.203 & 0.165 \\
\hline \multirow[t]{5}{*}{ Mexico } & 1970 & 454.1 & 0.213 & 0.596 & 0.022 & 682.0 & 0.021 & 0.770 & 0.085 \\
\hline & 1975 & 1062.2 & 0.297 & 0.416 & 0.010 & 1337.0 & 0.025 & 0.720 & 0.078 \\
\hline & 1980 & 2156.9 & 0.231 & 0.541 & 0.026 & 2688.0 & 0.022 & 0.667 & 0.064 \\
\hline & 1983 & 6194.9 & 0.067 & 0.782 & 0.022 & 2579.2 & 0.020 & 0.744 & 0.052 \\
\hline & 1984 & 7110.6 & 0.058 & 0.805 & 0.017 & 3024.3 & 0.022 & 0.739 & 0.043 \\
\hline \multirow[t]{5}{*}{ Uruguay } & 1970 & 42.0 & 0.259 & 0.22 & 0 & 192.0 & 0.098 & 0.057 & 0.001 \\
\hline & 1975 & 114.2 & 0.424 & 0.198 & 0.001 & 265.0 & 0.228 & 0.012 & 0.021 \\
\hline & 1980 & 401.8 & 0.463 & 0.135 & 0.001 & 657.0 & 0.058 & 0.032 & 0.031 \\
\hline & 1983 & 313.3 & 0.319 & 0.236 & 0.006 & 729.8 & 0.202 & 0.040 & 0.025 \\
\hline & 1984 & 345.4 & 0.364 & 0.275 & 0.005 & 575.3 & 0.202 & 0.053 & 0.042 \\
\hline \multirow[t]{5}{*}{ Venezuela } & 1970 & 39.0 & 0.623 & 0.126 & 0.001 & 231.4 & 0.006 & 0.588 & 0.021 \\
\hline & 1975 & 103.4 & 0.428 & 0.320 & 0 & 378.4 & 0.016 & 0.621 & 0.004 \\
\hline & 1980 & 692.8 & 0.213 & 0.124 & 0.375 & 423.8 & 0.034 & 0.413 & 0.009 \\
\hline & 1983 & 564.5 & 0.128 & 0.244 & 0.371 & 528.3 & 0.026 & 0.489 & 0.047 \\
\hline & 1984 & 926.9 & 0.170 & 0.417 & 0.218 & 324.7 & 0.017 & 0.489 & 0.016 \\
\hline
\end{tabular}

Source: ECLA/CEPAL. 
TABLE 14

Middle Income Countries

Exports of Manufactured and Primary Goods - 1970-1984

\begin{tabular}{|c|c|c|c|c|c|c|c|c|c|}
\hline \multirow[b]{2}{*}{ Country } & \multirow[b]{2}{*}{ Yeax } & \multicolumn{4}{|c|}{ Manufactured Exports } & \multicolumn{4}{|c|}{ Primary Exports } \\
\hline & & $\begin{array}{l}\text { Total } \\
\text { U.S.S } \\
\end{array}$ & $\begin{array}{c}\text { L.A \& } \\
\text { Caribbean }\end{array}$ & U.S. & Japan & $\begin{array}{l}\text { Total } \\
\text { U.S.S } \\
\end{array}$ & $\begin{array}{c}\text { L.A. \& } \\
\text { Caribbean }\end{array}$ & U.S. & $\underline{J a p a n}$ \\
\hline \multirow[t]{5}{*}{ Colombia } & 1970 & 62.8 & 0.386 & 0.325 & 0.043 & 591.3 & 0.062 & 0.347 & 0.030 \\
\hline & 1975 & 308.1 & 0.443 & 0.203 & 0.030 & 1050.8 & 0.114 & 0.316 & 0.017 \\
\hline & 1980 & 777.4 & 0.501 & 0.174 & 0.046 & 3055.2 & 0.060 & 0.293 & 0.036 \\
\hline & 1983 & 549.0 & 0.365 & 0.281 & 0.063 & 2032.5 & 0.038 & 0.269 & 0.051 \\
\hline & 1984 & 591.3 & 0.328 & 0.302 & 0.047 & 2344.3 & 0.031 & 0.314 & 0.053 \\
\hline \multirow[t]{5}{*}{ Paraguay } & 1970 & 5.7 & 0.365 & 0.359 & 0.004 & 58.4 & 0.387 & 0.111 & 0.006 \\
\hline & 1975 & 30.8 & 0.465 & 0.039 & 0.057 & 143.2 & 0.335 & 0.101 & 0.009 \\
\hline & 1980 & 36.5 & 0.733 & 0.100 & 0.011 & 273.7 & 0.416 & 0.087 & 0.012 \\
\hline & 1983 & 18.1 & 0.510 & 0.181 & 0.006 & 240.1 & 0.389 & 0.073 & 0.008 \\
\hline & 1984 & 19.0 & 0.253 & 0.508 & 0.003 & 315.5 & 0.386 & 0.026 & 0.025 \\
\hline \multirow[t]{5}{*}{ Costa Rica } & 1970 & 42.9 & 0.853 & 0.017 & 0 & 185.7 & 0.092 & 0.433 & $0.1 \dot{8} 2$ \\
\hline & 1975 & 117.7 & 0.822 & 0.021 & 0 & 364.3 & 0.146 & 0.440 & 0.027 \\
\hline & 1980 & 289.7 & 0.799 & 0.049 & 0 & 836.8 & 0.190 & 0.489 & 0.039 \\
\hline & 1983 & 228.6 & 0.738 & 0.069 & 0 & 559.0 & 0.101 & 0.692 & 0.028 \\
\hline & 1984 & 226.1 & 0.680 & 0.144 & 0 & 707.1 & 0.058 & 0.460 & 0.007 \\
\hline \multirow[t]{5}{*}{ Guatemala } & 1970 & 81.6 & 0.937 & 0.026 & 0.003 & 208.4 & 0.134 & 0.384 & 0.094 \\
\hline & 1975 & 156.1 & 0.896 & 0.039 & 0 & 467.0 & 0.082 & 0.295 & 0.069 \\
\hline & 1980 & 428.1 & 0.739 & 0.030 & 0.020 & 1029.1 & 0.108 & 0.375 & 0.040 \\
\hline & 1983 & 279.2 & 0.896 & 0.030 & 0 & 771.8 & 0.139 & 0.447 & 0.054 \\
\hline & 1984 & 257.0 & 0.862 & 0.059 & 0 & 811.5 & 0.024 & 0.468 & 0.060 \\
\hline \multirow[t]{5}{*}{ Ecuador } & 1970 & 3.3 & 0.79 & 0.132 & 0.007 & 185.6 & 0.049 & 0.521 & 0.060 \\
\hline & 1975 & 21.5 & 0.761 & 0.183 & 0.011 & 364.5 & 0.070 & 0.548 & 0.012 \\
\hline & 1980 & 75.3 & 0.875 & 0.081 & 0.006 & 673.7 & 0.072 & 0.468 & 0.022 \\
\hline & 1983 & 22.2 & 0.793 & 0.132 & 0.005 & 601.2 & 0.046 & 0.444 & 0.008 \\
\hline & 1984 & 21.1 & 0.665 & 0.157 & 0.007 & 764.1 & 0.071 & 0.713 & 0.022 \\
\hline \multirow[t]{5}{*}{ Peru } & 1970 & 320.9 & 0.059 & 0.514 & 0.077 & 715.7 & 0.062 & 0.253 & 0.164 \\
\hline & 1975 & 349.7 & 0.191 & 0.278 & 0.128 & 942.5 & 0.147 & 0.232 & 0.113 \\
\hline & 1980 & 1396.3 & 0.267 & 0.166 & 0.087 & 1286.4 & 0.148 & 0.225 & 0.146 \\
\hline & 1983 & 735.1 & 0.192 & 0.426 & 0.041 & 809.9 & 0.109 & 0.311 & 0.190 \\
\hline & 1984 & 789.4 & 0.214 & 0.386 & 0.092 & 1017.7 & 0.118 & 0.249 & 0.158 \\
\hline
\end{tabular}

Source: ECLA/CEPAL. 
TABLE 15

Lower Income Latin American Countries:

Exports of Manufactured and Primary Goods

$1970-1984$

Manufactured Exports

$\begin{array}{ll} & \\ \text { Gountry } & \text { Year } \\ \text { Nicaragua } & 1970 \\ & 1975 \\ & 1980 \\ & 1983 \\ & 1984\end{array}$

E1 Salvador 1970

1975

1980

1983

1984

Honduras $\quad 1970$

1975

1980

1983

1984

Bolivia

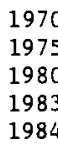

Total L.A \&

U.S.S Garibbean

$\begin{array}{ll}28.2 & 0.953 \\ 63.0 & 0.916 \\ 59.9 & 0.880 \\ 34.7 & 0.595 \\ 32.1 & 0.208\end{array}$

67.2

142.8

269.2

165.9

164.0

14.9

33.3

103.7

60.0

48.4

0.960

0.909

0.918

0.851

0.844

0.852

0.744

0.689

0.691

0.644

102.0

187.9

293.0

191.5

0.037

0.117

0.149

0.107

207.6
0.083

\section{U., S.}

\subsection{0}

0.0660

0.069

0.002

0.012

\begin{abstract}
0.016
\end{abstract}
0.017

0.026

0.057

0.077

\subsection{0}

$0.116 \quad 0.001$

0.205

0.225

0.001

0.276

\begin{abstract}
$0.190 \quad 0$
\end{abstract}
0.338

0.487

0.546

0.366

0.012

0.006

0.001
Primary Exports

\section{Total L.A. \&}

U.S.S Garibbean U.S. Japan

$\begin{array}{llll}146.1 & 0.253 & 0.347 & 0.152 \\ 306.4 & 0.118 & 0.324 & 0.158 \\ 393.9 & 0.076 & 0.200 & 0.167 \\ 393.9 & 0.076 & 0.200 & 0.167 \\ 354.5 & 0.064 & 0.137 & 0.269 \\ & & & \\ 159.9 & 0.052 & 0.215 & 0.157 \\ 364.3 & 0.035 & 0.375 & 0.165 \\ 430.6 & 0.076 & 0.480 & 0.079 \\ 290.2 & 0.069 & 0.420 & 0.099 \\ 434.3 & 0.102 & 0.465 & 0.077\end{array}$

148.6

0.061

0.085

0.028

$0.608 \quad 0.016$

249.6

$0.576 \quad 0.036$

705.9

0.054

0.581

0.587

649.4

0.054

0.549

0.048

116.7

0.068

$0.511 \quad 0.186$

188.0

0.162

0.422

499.0

0.181

0.319

0.103

184.6

0.071

282

$\begin{array}{ll}0.204 & 0.043\end{array}$

Source: ECLA/CEPAL. 


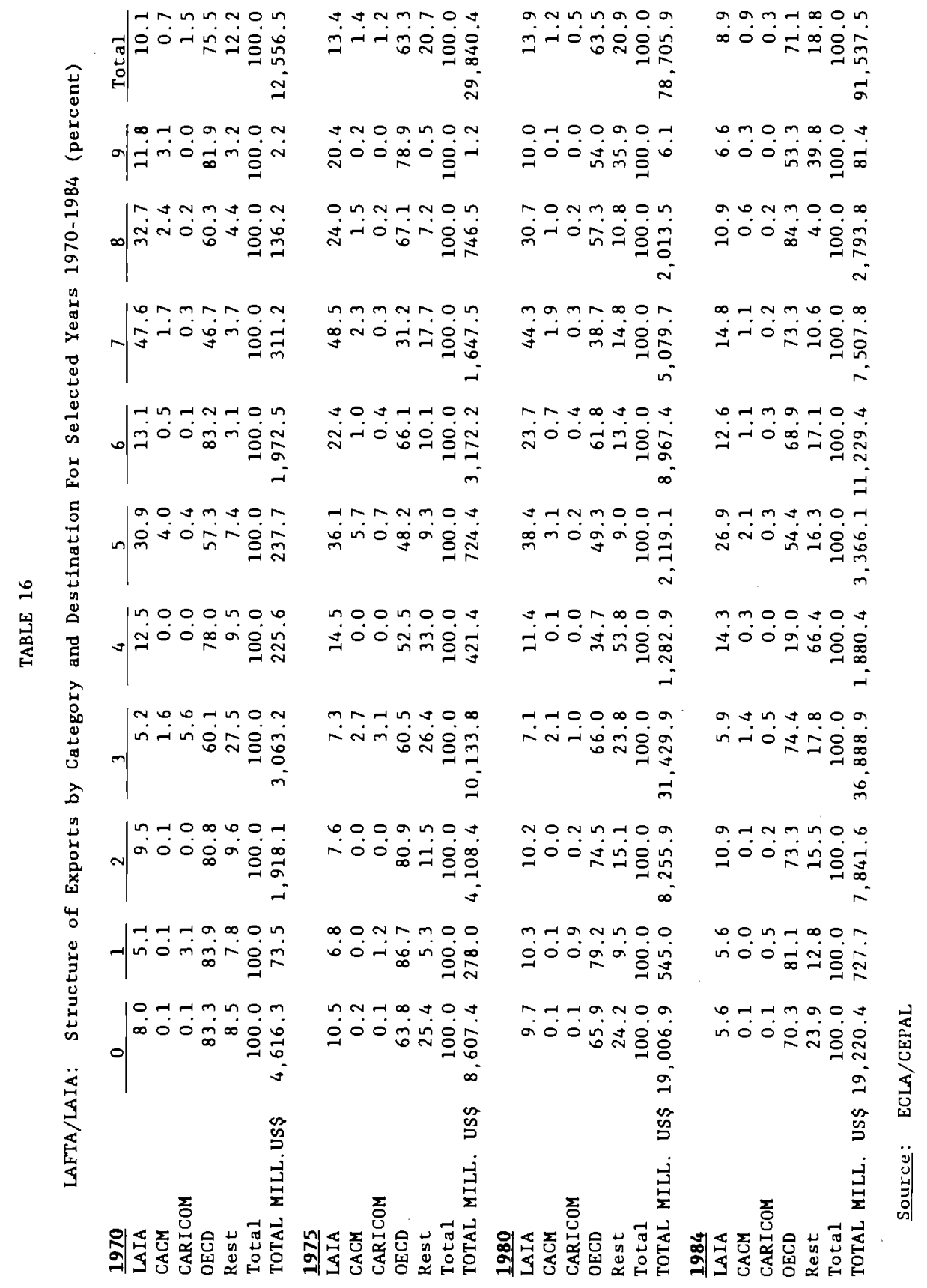




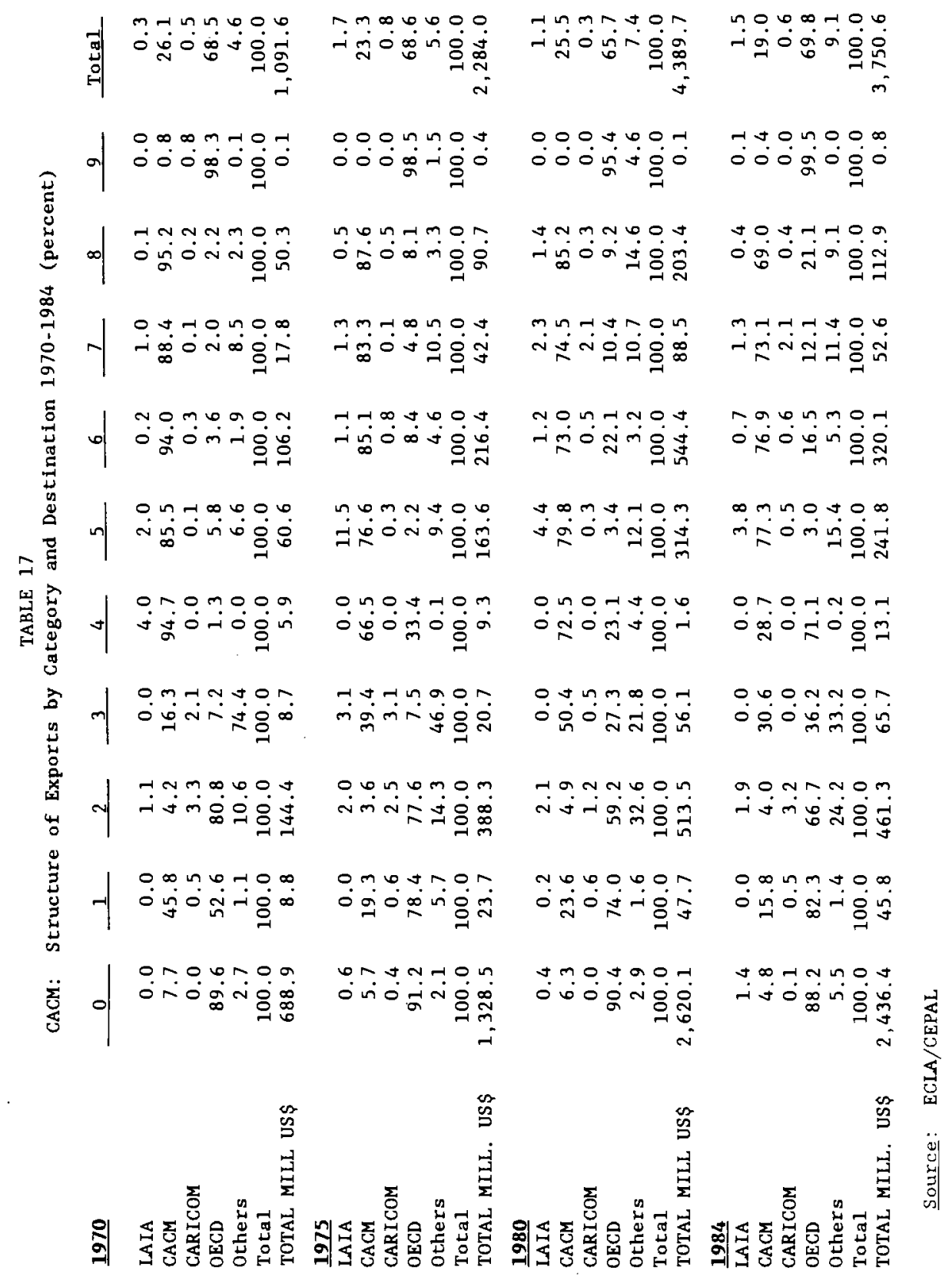


TABLE 18

Coverage of Some NonTariff Barriers in Selected

Latin American Countries: 1983

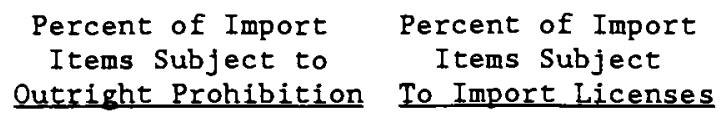

Argentina

- All Products

23

29

Brazil

- All Products

42

n.a.

- Textiles

93

n.a.

- Agriculture

86

n.a.

- Wood

80

n.a.

Chile

- All Products

0

0

Colombia

- All Products

n.a.

60

Ecuador

- All Products

n. a.

- Agriculture

71

n.a.

Mexico

- All Products

n.a.

82

Source: ALADI (1984). 
TABLE 19

Evolution of Trade Restrictions and Exchange Controls

In Two Years Preceding 17 Balance of Payments Crises in Latin America

\begin{tabular}{|c|c|c|c|}
\hline Episode & $\begin{array}{c}\text { Payments } \\
\text { Restrictions on } \\
\text { Current Transactions }\end{array}$ & $\begin{array}{l}\text { Tariffs, Duties and } \\
\text { Cost Related Measures }\end{array}$ & $\begin{array}{c}\text { Restrictions on } \\
\text { Capital Iransactions }\end{array}$ \\
\hline $\begin{array}{l}\text { Argentina } \\
(1970)\end{array}$ & $\begin{array}{l}\text { - Increased restric- } \\
\text { tions on capital } \\
\text { goods. } \\
\text { - Public sector pay- } \\
\text { ments monitored. } \\
\text { - All foreign ex- } \\
\text { change transactions } \\
\text { suspended for } 10 \\
\text { days prior to } \\
\text { devaluation. }\end{array}$ & $\begin{array}{l}\text {-Advanced deposits of } \\
40 \text { for } 180 \text { days. } \\
\text { - Taxes on traditional } \\
\text { exports. } \\
\text { - Special regimes and } \\
\text { exceptions abolished. }\end{array}$ & $\begin{array}{l}\text { - No restrictions, } \\
\text { and no changes } \\
\text { prior to devalua- } \\
\text { tion. }\end{array}$ \\
\hline $\begin{array}{l}\text { Bolivia } \\
(1972)\end{array}$ & $\begin{array}{l}\text { - Public sector pay- } \\
\text { ments highly } \\
\text { controlled. } \\
\text {-QRs on foodstuffs, } \\
\text { cattle, cotton. } \\
\text { - Between May and Aug. } \\
\text { a number of imports } \\
\text { are prohibited (1972) }\end{array}$ & $\begin{array}{l}\text { - Custom charge of } \\
158 \text { is in place in } \\
1970 . \\
20 \text { tax on exports } \\
\text { imposed. } \\
\text {. }\end{array}$ & $\begin{array}{l}\text { - Restrictive initial } \\
\text { condition. No } \\
\text { changes. }\end{array}$ \\
\hline $\begin{array}{l}\text { Bolivia } \\
\text { (1979) }\end{array}$ & $\begin{array}{l}\text { - Payments restric- } \\
\text { tions are increased } \\
\text { for a number of } \\
\text { ltems in year prior. } \\
\text { - Exchange transac- } \\
\text { tions suspended for } \\
8 \text { days prior to } \\
\text { devaluation. }\end{array}$ & $\begin{array}{l}\text { - In } 1977 \text { most imports } \\
\text { subject to } 5-25 \\
\text { advanced deposit. } \\
\text { - Exceptions for duty } \\
\text { payments eliminated } \\
\text { for essentials (Feb.) } \\
\text {-500 advanced deposit } \\
\text { imposed on } 600 \text { items. }\end{array}$ & $\begin{array}{l}\text {-All capital move- } \\
\text { ments requires } \\
\text { authorization. } \\
\text { - Celling set on new } \\
\text { foreign borrowing. }\end{array}$ \\
\hline $\begin{array}{l}\text { Bolivia } \\
\text { (1982) }\end{array}$ & $\begin{array}{l}\text { - Imports of indust- } \\
\text { rial goods produced } \\
\text { locally are prohib- } \\
\text { ited. } \\
\text { - All sales of foreign } \\
\text { exchange subject to } \\
\text { authorization. }\end{array}$ & $\begin{array}{l}\text { - In } 1980 \text { advanced } \\
\text { deposits of } 58 \text { to } \\
258 \text {. } \\
\text {-1981: advanced } \\
\text { deposits reduced; } \\
\text { import duties } \\
\text { reduced. }\end{array}$ & $\begin{array}{l}\text { - July } 1982 \text {, payments } \\
\text { tions were tight- } \\
\text { ened in July } 1982 .\end{array}$ \\
\hline $\begin{array}{l}\text { Chile } \\
\text { (1982) }\end{array}$ & $\begin{array}{l}\text { - Payments highly } \\
\text { liberalized. No re- } \\
\text { strictions imposed. }\end{array}$ & $\begin{array}{l}\text { - Flat import tariff } \\
\text { of } 10 \text { not altered } \\
\text { prior to devaluation. }\end{array}$ & $\begin{array}{l}\text { - Some restrictions } \\
\text { on capital move- } \\
\text { ments are in place } \\
\text { preceding devalua- } \\
\text { tion. No changes } \\
\text { prior to abandon- } \\
\text { ment of peg. }\end{array}$ \\
\hline
\end{tabular}


Table 19 (cont)

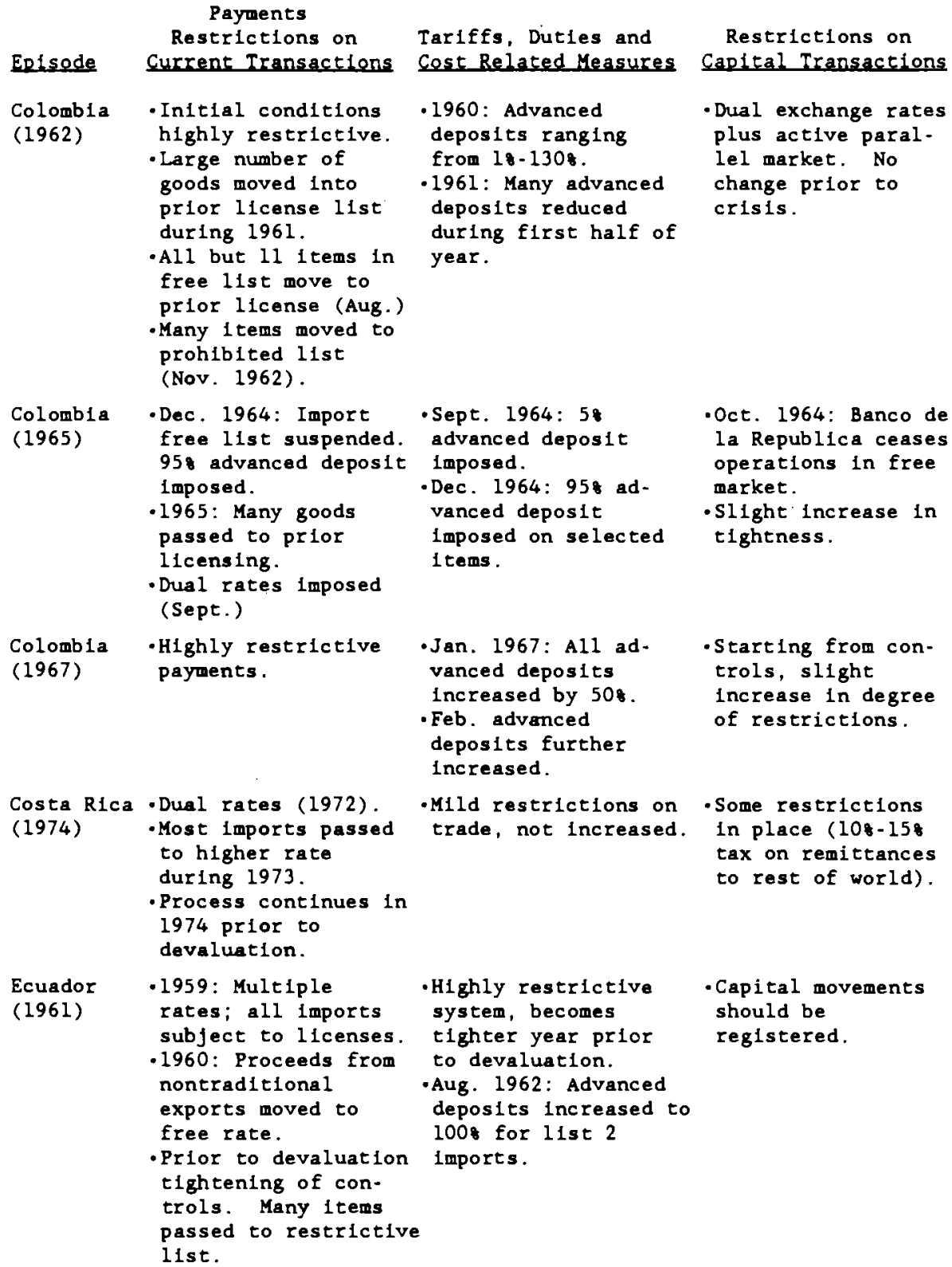

-Jan. 1967: All ad. vanced deposits Increased by $50 \%$.

- Eeb. advanced deposits further increased.

- Dual exchange rates plus active parallel market. No change prior to crisis.

- Oct. 1964: Banco de la Republica ceases operations in free market.

vanced deposit Imposed on selected - Slight increase in tightness.

Ecuador (1961) 


\begin{tabular}{|c|c|c|c|}
\hline Episode & $\begin{array}{c}\text { Payments } \\
\text { Restrictions on } \\
\text { Current Iransactions } \\
\end{array}$ & $\begin{array}{l}\text { Tariffs, Duties and } \\
\text { Cost Related Measures }\end{array}$ & $\begin{array}{c}\text { Restrictions on } \\
\text { Capital Transactions }\end{array}$ \\
\hline $\begin{array}{l}\text { Ecuador } \\
\text { (1970) }\end{array}$ & $\begin{array}{l}\text { - Two types of import } \\
\text { lists with different } \\
\text { degrees of restric- } \\
\text { tions. } \\
\text {-Jan. -July } 1970 \text { : In- } \\
\text { creased restrictions } \\
\text { including } \$ 400 \text { quota } \\
\text { on travelers. }\end{array}$ & $\begin{array}{l}\text {-1968: List } 1 \text { subject } \\
\text { to } 158 \text { duties; List } 2 \\
\text { subject to } 70 \text { duty. } \\
\text {-1969: Increased sur- } \\
\text { charges hiked. } \\
\text {-Jan. 1970: Duties } \\
\text { raised to } 408 \text { for } \\
\text { List } 1 \text { and } 808 \text { for } \\
\text { List 2. } \\
\text { May: Further in- } \\
\text { creases in surcharges. }\end{array}$ & $\begin{array}{l}\text { - June } 1970 \text { : In- } \\
\text { creased restric- } \\
\text { tions. Banks and } \\
\text { nonbanks required } \\
\text { to sell all foreign } \\
\text { exchange holdings } \\
\text { to Central Bank. }\end{array}$ \\
\hline $\begin{array}{l}\text { Ecuador } \\
(1982)\end{array}$ & $\begin{array}{l}\text {-Same List } 1 / \text { List } 2 \\
\text { structure. Multiple } \\
\text { rates. } \\
\text {-1981: Increased } \\
\text { restrictions. }\end{array}$ & $\begin{array}{l}\text { - Feb. } 1981 \text { increase in } \\
\text { coverage and rates of } \\
\text { advanced deposits. } \\
\text { - June: Import tariffs } \\
\text { raised in } 500 \text { items. }\end{array}$ & $\begin{array}{l}\text { Slight increase in } \\
\text { restrictiveness. }\end{array}$ \\
\hline $\begin{array}{l}\text { Mexico } \\
(1982)\end{array}$ & $\begin{array}{l}\text { - Initial conditions: } \\
\text { Import licensing and } \\
\text { import quotas. } \\
\text { - 1981: Import licens- } \\
\text { Ing greatly } \\
\text { increased. }\end{array}$ & $\begin{array}{l}\text { - May 1981: Duties in- } \\
\text { cresed in } 374 \text { Items. } \\
\text {-July: Further } \\
\text { Increases in duties } \\
\text { levels. } \\
\text { - Nov.: Duties hiked } \\
\text { for } 120 \text { 1tems. }\end{array}$ & $\begin{array}{l}\text { - No change in } \\
\text { capital controls. in } \\
\text { period preceding } \\
\text { devaluation. }\end{array}$ \\
\hline $\begin{array}{l}\text { Nicaragua } \\
(1979)\end{array}$ & $\begin{array}{l}\text {-2 groups of imports. } \\
\text {-Sales of foreign } \\
\text { exchange at official } \\
\text { rate restricted. } \\
\text { - Licenses hiked in } \\
\text { 1978/79. } \\
\text { - Multiple rates 1m- } \\
\text { posed (Apr. 1979). }\end{array}$ & $\begin{array}{l}\text { - Nov. 1979: Weekly } \\
\text { foreign exchange } \\
\text { allocation for } \\
\text { imports imposed. }\end{array}$ & $\begin{array}{l}\text { - Increased } \\
\text { restrictions. } \\
\text {. }\end{array}$ \\
\hline $\begin{array}{l}\text { Peru } \\
\text { (1967) }\end{array}$ & $\begin{array}{l}\text { - Initial conditions } \\
\text { (1965): No licenses } \\
\text { required (except } \\
\text { for } 12 \text { 1tems). } \\
\text { - In } 1967 \text { a number of } \\
\text { restrictions were } \\
\text { 1mposed. Exports } \\
\text { required licenses } \\
\text { (Oct.). Exports } \\
\text { proceeds surrendered } \\
\text { for certificates. }\end{array}$ & $\begin{array}{l}\text {-Aug. 1966: Most } \\
\text { imports subject to } \\
\text { surcharge. } \\
\text { - June } 1967: \text { General- } \\
\text { lzed hike in 1mport } \\
\text { duties. }\end{array}$ & $\begin{array}{l}\text {-Very open Inltial } \\
\text { conditions. } \\
\text { - Sept. 1967: A } \\
\text { moratoriun on pay- } \\
\text { ments of foreign } \\
\text { debt declared. } \\
\text { Lifted after } 16 \\
\text { days. } \\
\text { - Slight increase in } \\
\text { degree of restric- } \\
\text { tions. }\end{array}$ \\
\hline
\end{tabular}


Table 19 (cont)

\begin{tabular}{|c|c|c|c|}
\hline Episode & $\begin{array}{c}\text { Payments } \\
\text { Restrictions on } \\
\text { Current Transactions }\end{array}$ & $\begin{array}{l}\text { Tariffs, Duties and } \\
\text { Cost Related Measures }\end{array}$ & $\begin{array}{c}\text { Restrictions on } \\
\text { Capltal Iransactions }\end{array}$ \\
\hline $\begin{array}{l}\text { Peru } \\
(1975)\end{array}$ & $\begin{array}{l}\text { - Inftial conditions } \\
\text { (1973): Severe } \\
\text { restrictlons. Mul- } \\
\text { tiple exchange } \\
\text { rates. Licenses or } \\
\text { prior approval } \\
\text { required for almost } \\
\text { every Item. } \\
\text { - No major changes } \\
\text { during year prior to } \\
\text { devaluation. }\end{array}$ & $\begin{array}{l}\text {-Restrictive initial } \\
\text { cond1tions. During } \\
\text { l974 degree of } \\
\text { restrictiveness is } \\
\text { Increased. } \\
\text { - Jan. 1975: 128 } \\
\text { surcharge on all } \\
\text { Imports. }\end{array}$ & $\begin{array}{l}\text {-Very restrictive } \\
\text { Inltial conditions. } \\
\text { - No changes during } \\
\text { year prior to } \\
\text { devaluation. }\end{array}$ \\
\hline $\begin{array}{l}\text { Venezuela } \\
\text { (1964) }\end{array}$ & $\begin{array}{l}\text { - Multiple rates. } \\
\text { - Some restrictions } \\
\text { Inltially, with } \\
\text { licenses required } \\
\text { on some ltems. } \\
\text { - No changes in year } \\
\text { prior to devalua- } \\
\text { tion. }\end{array}$ & $\begin{array}{l}\text { - No changes in year } \\
\text { prior to devaluation. }\end{array}$ & $\begin{array}{l}\text {-Almost complete } \\
\text { capital mobility } \\
\text { whlch is malntalned } \\
\text { throughout episode. }\end{array}$ \\
\hline
\end{tabular}

Source: IMF Yearbook on Exchange Arrangements and Restrictions (several isgues) and Pick's Currency Yearbook. 
TABLE 20

Developed Countries' Tariff and NonTariff Barriers: 1983

\section{Importer \\ Exporter}

Latin American LDCs

African LDCs
Asian LDCs
Other Developed
Countries

Source: CEPAL (1986g).

\begin{tabular}{|c|c|c|c|c|c|}
\hline \multicolumn{2}{|r|}{ U.S.A. } & \multicolumn{2}{|c|}{ EEC } & \multicolumn{2}{|r|}{ Japan } \\
\hline $\begin{array}{c}\text { Average } \\
\text { Tariff } \\
\text { Rate } \\
\end{array}$ & $\begin{array}{l}\text { Proportion } \\
\text { of Imports } \\
s, t \text {.NTB's }\end{array}$ & $\begin{array}{c}\text { Average } \\
\text { Tariff } \\
\text { Rate } \\
\end{array}$ & $\begin{array}{l}\text { Proportion } \\
\text { of Imports } \\
\text { s.t. NTB's }\end{array}$ & $\begin{array}{c}\text { Average } \\
\text { Tariff } \\
\text { Rate } \\
\end{array}$ & $\begin{array}{l}\text { Proportion } \\
\text { of Imports } \\
\text { s.t. NTB's }\end{array}$ \\
\hline 2.0 & 7.3 & 2.6 & 27.7 & 5.1 & 18.5 \\
\hline 0.7 & 0.8 & 0.2 & 10.4 & 2.4 & 10.6 \\
\hline 3.3 & 10.2 & 0.9 & 9.9 & 3.7 & 4.8 \\
\hline 3.1 & 6.8 & 3.4 & 19.7 & 8.6 & 19.9 \\
\hline
\end{tabular}




\section{TABLE 21}

LAIA: Recent Evolution and ECLA's Projections

$$
\begin{gathered}
\text { of Intraregional Trade } \\
\text { (percent) }
\end{gathered}
$$

$\begin{array}{ccc} & \begin{array}{c}\text { Intraregional Exports } \\ + \\ \text { Year }\end{array} & \begin{array}{c}\text { Intraregional Imports } \\ +\end{array} \\ 1980 & 13.8 & 12.6 \\ 1981 & 13.1 & 13.4 \\ 1982 & 12.2 & 14.9 \\ 1983 & 8.8 & 15.3 \\ 1984 & 8.9 & 15.9 \\ \text { Projected Values } & & \\ 1985 & 9.0 & 14.8 \\ 1986 & 9.7 & 15.6 \\ 1987 & 10.4 & 16.4 \\ 1988 & 11.2 & 17.0 \\ 1989 & 12.0 & 17.8 \\ 1990 & 12.9 & 18.6 \\ 1991 & 13.9 & 19.5 \\ 1992 & 14.9 & 20.4 \\ 1993 & 16.0 & 21.2 \\ 1994 & 17.2 & 22.2 \\ & & \end{array}$

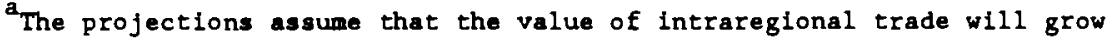
at an annual rate of 16 .

Source: CEPAL (1986d). 